\title{
Disentangling the effects of tree species and microclimate on heterotrophic and autotrophic soil respiration in a Mediterranean ecotone forest
}

\author{
María José Fernández-Alonso , Eugenio Díaz-Pinés , Carlos Ortiz , Agustín Rubio
}

\begin{abstract}
A B S T R A C T
Understanding how forest ecosystems influence the response of soil respiration $\left(\mathrm{R}_{\mathrm{S}}\right)$ to climate drivers is essential to accurately predict soil carbon dioxide $\left(\mathrm{CO}_{2}\right)$ fluxes in a changing environment. This is particularly crucial in areas of contact between coniferous and broadleaved forests in the Mediterranean region which are already experiencing a warmer and drier climate. We present a case study in a Mediterranean ecotone forest where $\mathrm{R}_{S}$ components -heterotrophic $\left(\mathrm{R}_{\mathrm{H}}\right)$ and autotrophic $\left(\mathrm{R}_{\mathrm{A}}\right)$ - were monitored beneath pure Scots pine (Pinus sylvestris L.) and Pyrenean oak (Quercus pyrenaica Willd.) stands using the root-trenching method. We used generalized linear models to predict the soil $\mathrm{CO}_{2}$ efflux based on interactions between soil water conent (SWC) and soil temperature. Regardless of the tree species, we found that the strong and inverse water availability and thermal seasonality of the Mediterranean climate intensely constrained soil microbial activity. The incorporation of the soil temperature-moisture covariation thus greatly improved the quality of the models compared to approaches that consider soil temperature alone. We also identified species-specific responses influencing both the total amount of $\mathrm{R}_{\mathrm{A}}$ and its sensitivity to environmental variables. Root respiration in the Scots pine stand showed greater vulnerability to the decline in SWC throughout the summer than in the oak stand. The $R_{A}$ in the Pyrenean oak stand was mainly limited by low soil temperatures in winter, indicating low maintenance rates during vegetative dormancy. Mean annual $\mathrm{R}_{\mathrm{H}}$ rates were highest in the Scots pine stand, probably driven by the larger litterfall rates and soil carbon (C) stocks; however, the apparent turnover rate of soil organic $\mathrm{C}$ in the oak stand was almost twice as fast as in the pine stand. While our observations are limited to a case study, our work shows that both soil moisture and forest composition can significantly control the temperature dependence of $\mathrm{R}_{\mathrm{S}}$ components under a Mediterranean climate.
\end{abstract}

\section{Introduction}

Land cover changes in forests occur to a large extent as a result of climate change and modifications in forest practices (Allen et al., 2010; Peñuelas and Boada, 2003). Alterations in the dominant tree species can significantly alter soil respiration $\left(R_{S}\right)$, which in turn affects the global carbon (C) cycle, since soils are responsible for $60-90 \%$ of the carbon dioxide $\left(\mathrm{CO}_{2}\right)$ released into the atmosphere in terrestrial ecosystems (Goulden et al., 1996). Soil $\mathrm{CO}_{2}$ efflux is the outcome of the metabolic processes of plant roots (autotrophic respiration, $R_{A}$ ) and microbial communities (heterotrophic respiration, $\mathbf{R}_{\mathrm{H}}$ ) (Hanson et al., 2000; Kuzyakov, 2006). It is therefore important to determine the contribution of each component to $\mathrm{R}_{\mathrm{S}}$ and their dependence on climate drivers to gain a deeper insight into the effects of changes in forest composition on soil C cycling and respiration (Barba et al., 2016; BondLamberty et al., 2004a).

It is well known that temperature is the main factor controlling soil metabolic activity, so the kinetics of released $\mathrm{CO}_{2}$ have usually been modelled by a broad set of temperature-dependent functions (Fang and Moncrieff, 2001; Kirschbaum, 1995; O'Connell, 1990; Tuomi et al., 2008). However, the temporal variability of $R_{H}$ observed in field experiments captures not only its dependence on soil temperature and resource quality, but also reflects the limitations on decomposition caused by soil water content (SWC) (Chang et al., 2014; Davidson and

\footnotetext{
Abbreviations: $\mathrm{R}_{\mathrm{S}}$, soil respiration; $\mathrm{R}_{\mathrm{H}}$, heterotrophic respiration; $\mathrm{R}_{\mathrm{A}}$, autotrophic respiration; $\mathrm{SWC}$, soil water content; $\mathrm{SWB}$, soil water balance; WHC, maximum soil

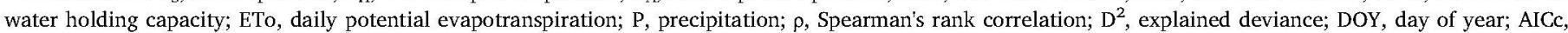
corrected Akaike Information Criterion; $\mathrm{W}_{\mathrm{AIC}}$, Akaike weights
} 
Janssens, 2006; Lellei-Kovács et al., 2016); e.g. drought restricts substrate availability while excess water slows oxygen diffusion for decay processes. Soil microclimate limitations at the field scale can also cause physiological stress to both microbes and plants, which may display different response behaviours in $\mathbf{R}_{\mathrm{H}}$ and $\mathrm{R}_{\mathrm{A}}$ (Bond-Lamberty et al., 2004a; Galiano et al., 2011; Manzoni et al., 2014). Studies investigating the combined effects of soil temperature and SWC on $\mathrm{R}_{\mathrm{S}}$ components are scarce in Mediterranean and semiarid ecosystems, although both climate drivers may significantly influence soil $\mathrm{C}$ efflux (Chang et al., 2014; Lellei-Kovács et al., 2016; Rey et al., 2002; Tedeschi et al., 2006). There is therefore a need for experimental approaches that address the dynamic interaction between soil temperature and SWC in decomposition processes and root activities in order to understand the seasonal variability of $R_{S}$ in forest ecosystems.

Vegetation also controls $R_{S}$ and its fractions through its influence on litter quantity and quality, nutrient availability, microbial decomposer community, carbohydrate allocation patterns, root biomass, hydrological processes and surface soil temperatures (Bardgett and Wardle, 2010; Fernández-Alonso et al., 2018; Högberg et al., 2001; Salomón et al., 2015). On large spatial scales, the length of the plant-growing season is one of the major drivers of Rs (Chang et al., 2014; Goulden et al., 1996) as it regulates the gross primary production of the ecosystems (Reichstein et al., 2003). Gross primary production stimulates the total metabolic activity in the soil through the net primary production, which provides the inputs of above- and belowground litter for microbial decomposition (Chang et al., 2014; Reichstein et al., 2003), and through the fresh photosynthetic products or tree carbohydrate reserves that fuel the metabolic activity of the root systems (Phillips et al., 2016). Variations in seasonal patterns of $\mathbf{R}_{S}$ across species may thus be the result of differences in the response of $R_{A}$ and $R_{H}$ to soil microclimate variables (Bond-Lamberty et al., 2004a). These differences in the relative contribution of $R_{A}$ and $R_{H}$ to $R_{S}$ could be particularly significant when comparing vegetation species with differences in leaf longevity such as coniferous and broadleaved forests (Curiel Yuste et al., 2004). It is therefore crucial to study the seasonal evolution of $R_{A}$ and $R_{H}$ in each forest type individually in order to improve the forecasts of $R_{S}$ rates with the predicted changes in species distribution.

The ecotones between conifers and broadleaved species in the Mediterranean basin conform a particularly relevant case where the effects of plant functional traits and environmental constraints on $\mathbf{R}_{\mathrm{S}}$ overlap. The contact limit between Scots pine forests (Pinus sylvestris $\mathrm{L}$.) and Pyrenean oak forests (Quercus pyrenainca Willd.) on the Iberian Peninsula is a representative example of these ecotones. In these sites the Scots pine is located at one of its southernmost geographical distribution limits, and locally in its lowermost altitudinal range (Martínez García and Montero, 2000), hence extreme drought events in the summer can potentially lead to episodes of pine die-off (Allen et al., 2010; Martínez-Vilalta and Piñol, 2002). The ongoing intensification of climate-change-driven drought in southern Europe (Stagge et al., 2017) is aggravating water stress in Scots pine and leading to its replacement by oak species (Galiano et al., 2010) such as the Pyrenean oak, which is better adapted to physiological drought and continental temperatures (Sánchez Palomares et al., 2008).

A three-year long case study was conducted to subtract in situ $\mathbf{R}_{\mathrm{A}}$ from $\mathbf{R}_{\mathrm{S}}$ using the root-exclusion method (Ewel et al., 1987), and to monitor the soil $\mathrm{CO}_{2}$ efflux in a specific ecotonal area between Scots pine and Pyrenean oak in the Valsaín mountains (central Iberian Peninsula). We aim to assess how seasonality and environmental conditions influence soil $\mathrm{CO}_{2}$ efflux depending on the functional composition of the forest (Scots pine vs. Pyrenean oak stands). First, we modelled the interaction between soil temperature and SWC on the $R_{S}$ components under pine and oak stands. We expected species-dependent effects, since the relevance and role of environmental drivers differ between tree species composition given their contrasting ecological strategies. Second, we used fitted models to predict the daily estimates of $R_{A}$ and $R_{H}$ for both tree species from daily soil temperature and SWC. Third, we calculated annual cumulative $\mathrm{R}_{\mathrm{H}}$ fluxes and compared the apparent soil $\mathrm{C}$ turnover rate in both forest types. We hypothesized that annual $R_{H}$ would be greatest in the pine stand, coinciding with the substantial amount of $\mathrm{C}$ stored in this soil as shown in previous studies. We further hypothesized that soil $\mathrm{C}$ turnover would be higher in the oak soil since soil organic matter is believed to be more stable in pine stands.

\section{Material and methods}

\subsection{Study site}

This study was conducted in the Valsaín forests $\left(40^{\circ} 51^{\prime} \mathrm{N}, 4^{\circ} 3^{\prime} \mathrm{W}\right.$, ETRS89) located on the north-western slopes of the Sierra de Guadarrama National Park (Central Range, Spain). The study area is at an altitude of about $1350 \mathrm{~m}$ a.s.l., where both Pyrenean oak and Scots pine stands are common. The mean annual temperature was $11.0^{\circ} \mathrm{C}$ and the mean annual precipitation $621 \mathrm{~mm}$ for the study period (Embalse del Pontón Alto weather station, National Meteorological Agency, $9 \mathrm{~km}$ away from the experimental sites). Soils are shallow and acidic ( $\mathrm{pH}$ values in $\mathrm{KCl}$ of 4.3 and 5.1 in topsoils under pine and oak respectively (Díaz-Pinés et al., 2011b)) and are Humic Cambisols (Soil Survey Staff, 2014) with sandy loam texture developed on siliceous bedrock, mostly granite and gneiss.

We selected two monospecific forests of Scots pine and Pyrenean oak that were representative in terms of past and current management -oak coppicing for charcoal and pine shelterwood for timber production- on stand structures in the Guadarrama Range, with limited environmental confounding factors (e.g. slope, altitude, bedrock and climate) since they were $1400 \mathrm{~m}$ apart. Soil organic matter content varied widely between the forests, especially in the upper soil layers (Table 1), resulting in a stock of $40.6 \mathrm{MgCha}^{-1}$ in the oak stand and $91.7 \mathrm{MgC} \mathrm{ha}^{-1}$ in the pine stand (forest floor and $0-50 \mathrm{~cm}$ of mineral soil (Díaz-Pinés et al., 2011b)). The Scots pine stand is managed under a

Table 1

Soil parameters required to calculate soil water holding capacity (WHC) in each forest stand. Compiled with data from Díaz-Pinés et al. (2011b) and methodology from Gandullo (1994). SOM: Soil organic matter content.

\begin{tabular}{|c|c|c|c|c|c|c|c|}
\hline Tree species & Slope & Depth $(\mathrm{cm})$ & Clay (\%) & Silt (\%) & SOM (\%) & Fine-earth $(<2 \mathrm{~mm})$ & WHC ( $\mathrm{mm} \mathrm{H}_{2} \mathrm{O} \mathrm{m}^{-1}$ depth) \\
\hline \multirow[t]{5}{*}{ Oak } & 0.18 & $0-5$ & 4 & 43 & 3.9 & 73 & 27.3 \\
\hline & & $5-10$ & 4 & 45 & 1.8 & 71 & 24.2 \\
\hline & & $10-20$ & 12 & 27 & 1.0 & 75 & 45.7 \\
\hline & & $20-30$ & 10 & 28 & 0.8 & 75 & 43.5 \\
\hline & & $0-30$ & & & & & 140.7 \\
\hline \multirow[t]{5}{*}{ Pine } & 0.21 & $0-5$ & 10 & 32 & 12.8 & 73 & 40.5 \\
\hline & & $5-10$ & 12 & 28 & 5.5 & 74 & 29.7 \\
\hline & & $10-20$ & 14 & 27 & 2.4 & 74 & 51.4 \\
\hline & & $20-30$ & 14 & 26 & 2.1 & 74 & 49.6 \\
\hline & & $0-30$ & & & & & 171.2 \\
\hline
\end{tabular}


uniform shelterwood system. The Pyrenean oak stand has traditionally been coppiced since the 12th century (Ximénez de Embún, 1977), although this practice was abandoned in the 1970s. The oak stand has around 60 -year old stems, $17.2 \mathrm{~m}^{2} \mathrm{ha}^{-1}$ basal area, $932 \mathrm{stems} \mathrm{ha}^{-1}$ and $9.7 \mathrm{~m}$ mean height; the pine stand has about 80 -year old trees, basal area of $64.3 \mathrm{~m}^{2} \mathrm{ha}^{-1}, 718$ trees ha ${ }^{-1}$ and $19 \mathrm{~m}$ mean tree height (DíazPinés et al., 2011b).

\subsection{Experimental design}

The root-trenching method was used to measure in situ $\mathbf{R}_{\mathrm{H}}$ and $\mathbf{R}_{\mathrm{S}}$ following the protocol of Hanson et al. (2000). In January 2014, we established two different rooting treatments, designated as 'control' and 'root-exclusion', with four replicated plots each $(1 \mathrm{~m} \times 1 \mathrm{~m})$ inside each forest stand at a distance of less than $2.5 \mathrm{~m}$ from the tree stems and with a mean distance of $30 \mathrm{~m}$ between the same treatment plots. In the rootexclusion treatment, we dug a ditch around the plot boundaries to physically isolate the soil matrix from the tree root system. A trench 40$\mathrm{cm}$ deep was considered sufficient to gauge the extent of the effective root depth, since the soil depth ranges from 20 to $50-60 \mathrm{~cm}$, and most of the roots are in the uppermost $15-20 \mathrm{~cm}$ of the soil profile. An antiroot geotextile was then placed vertically in the ditch and the outer part of the ditch was refilled with the previously extracted soil material. The surface was periodically clipped to ensure that herbs did not develop inside the trenched plots. Control plots -without the excision of rootsserved to monitor $R_{S}$. In the root-exclusion treatment it was assumed that $R_{\mathrm{A}}$ was completely suppressed and hence solely $\mathrm{R}_{\mathrm{H}}$ occurred - i.e. $\mathrm{CO}_{2}$ efflux derived from the microbial decomposition of soil organic matter and plant litter (Kuzyakov, 2006). The term $\mathrm{R}_{\mathrm{A}}$ refers to rootderived $\mathrm{CO}_{2}$ but may also comprise contributions from rhizomicrobial respiration from mycorrhizal fungi (Bond-Lamberty et al., 2004a; Kuzyakov, 2006).

\subsection{Soil $\mathrm{CO}_{2}$ efflux measurements}

Two polyvinylchloride respiratory collars $(20 \mathrm{~cm}$ in diameter) were inserted to a depth of $2 \mathrm{~cm}$ in the mineral soil in each plot. A fourmonth period was allowed to elapse before beginning soil respiration measurements in order to reduce the overestimation of $\mathbf{R}_{\mathrm{H}}$ while the severed pre-existing roots were decaying (Butler et al., 2012; Hanson et al., 2000). The 32 respiratory collars ( 2 forest types $\times 2$ treatments $\times 4$ replicated plots $\times 2$ respiratory collars) were monitored for soil $\mathrm{CO}_{2}$ efflux on a monthly basis from April 2014 to April 2017 (35 measurement campaigns). The influence of additional $\mathrm{C}$ efflux from old root decomposition in our field-registered values should be minimal, since the measurements presented here lasted three years (Díaz-Pinés et al., 2010). Manual measurements of soil $\mathrm{CO}_{2}$ efflux were taken using a non-steady-state through-flow chamber (Pumpanen et al., 2004). The respiratory collars were closed with a self-made chamber lid $(10 \mathrm{~cm}$ height and 4.041 volume) equipped with a rubber septum in the top where a stainless-steel needle vent was inserted to avoid overpressure and disturbing the $\mathrm{CO}_{2}$ diffusion from the soil into the chamber headspace (Hutchinson and Livingston, 2001). The respiratory chamber was also fitted with outlet and inlet Teflon tubes ( $2.5 \mathrm{~mm}$ inner diameter) coupled to a portable infrared gas analyser WMA-4 (PP Systems, Hertfordshire, United Kingdom). A pump circulated the air through the closed-path system at a constant rate of $0.51 \mathrm{~min}^{-1}$ during the closedchamber period $(5 \mathrm{~min})$. The headspace $\mathrm{CO}_{2}$ concentration was recorded from one minute after the chamber closure to discard fluctuations immediately after the lid onset at 30-s measurement intervals. Soil respiration rates were calculated as the linear increase in $\mathrm{CO}_{2}$ concentration in the time after the chamber closure, considering chamber volume, soil area, air temperature and air pressure, and expressed as $\mathrm{mg}$ $\mathrm{CO}_{2}-\mathrm{C} \mathrm{m}^{-2} \mathrm{~h}^{-1}$. No signs of flattening of the $\mathrm{CO}_{2}$ concentration in the headspace were observed throughout the closure time. The portable analyser was calibrated prior to the sampling events using $400 \mu \mathrm{LL}^{-1}$ of standard $\mathrm{CO}_{2}$ gas (Air Liquide, Madrid, Spain) under ambient air pressure. Soil respiration was measured between 07:30 and 16:30 h (local time). Although diel patterns are unlikely to occur in closed canopy stands, special care was taken to fully randomize the sampling sequence across plots in each measurement campaign to account for potential diel fluctuations. Average soil $\mathrm{CO}_{2}$ efflux at the plot level was computed for each measurement campaign to avoid within-group correlation in the statistical models during data analysis $(n=2$ respiratory collars).

During the soil $\mathrm{CO}_{2}$ efflux measurement campaigns, air and soil temperature and volumetric SWC were measured on the individual plots using probes, a Termistor Vertix 5989M (Herter Instruments, Barcelona, Spain) and a time-domain reflectometer (Field Scout TDR 100, Spectrum Technologies Inc., Aurora, IL, USA) respectively. Soil temperature was recorded on an hourly basis by means of three sensors randomly installed in each forest stand (DS1922L Thermochron, iButtonLink LCC, Whitewater, WI, USA). Soil temperature and SWC were measured at $10 \mathrm{~cm}$ depth in the mineral soil.

The root-exclusion treatment disrupts the root water uptake and may therefore produce disturbances in the soil water regime (DíazPinés et al., 2010; Hanson et al., 2000). In order to avoid potential bias on measured $\mathrm{CO}_{2}$ efflux caused by altered SWC in the trenched plots, we modelled the response surfaces of both $R_{S}$ and $R_{H}$ to the interaction effects between soil temperature and moisture measured in each sampling event (see data analysis in Section 2.5.). We subsequently used the fitted models to predict soil $\mathrm{CO}_{2}$ efflux throughout the study period using corrected values of daily SWC calculated with a soil water balance (SWB) model.

\subsection{Soil water balance for estimating soil water content}

The daily SWC during the study period was estimated with a SWB model (Thornthwaite and Mather, 1955). The input variables for the model were: potential evapotranspiration (ETo), maximum soil water holding capacity (WHC) and precipitation (P) in both forest stands. The model assumes that the depletion of SWC occurs exponentially on dry days when $\mathrm{P}<\mathrm{ETo}$, whereas there is a direct increase in SWC on humid days when P $>$ ETo (Botey et al., 2011). The ETo was calculated according to the modified equation of Penman-Monteith (Allen et al., 1998), based on meteorological variables registered at a nearby weather station (Embalse del Pontón Alto). Given that soil forests may present irregular properties at depth, the WHC was calculated from texture, organic matter content, slope and permeability of soil layers at different soil depths $(0-10,0-20,0-30$ and $0-50 \mathrm{~cm})$ following the physical model proposed by Gandullo (1994) (see also Domingo et al., 2006). The SWB was calculated from January 2014 (four months before the start of soil $\mathrm{CO}_{2}$ measurements) coinciding with water-saturated conditions (SWC $=$ WHC) in soils, as is common in winter in both forests. After initializing the SWB model for 4 months, we assumed the values predicted for daily SWCs were already adjusted to current field conditions at the onset of the soil $\mathrm{CO}_{2}$ measurements. Estimated SWCs calculated with the WHC for soil properties in the first $30-\mathrm{cm}$ of soil (Table 1) gave the best coefficients of determination with measured SWCs using the TDR probe $\left(R^{2}=0.77\right.$ and 0.79 in oak and pine forest stands respectively; p-value $<0.001$ ).

\subsection{Data analysis}

Differences in soil temperature and SWC across seasons both within and between tree species were evaluated separately with the nonparametric Kruskal-Wallis test, using Dunn's test for pairwise comparisons of mean rank sums (PMCR package, Pohlert, 2015). Annual and seasonal differences in soil microclimate variables between treatments were also assessed using the non-parametric Kruskal-Wallis test. Spearman's rank correlation ( $\rho$ ) was performed between soil temperature and SWC for each forest stand. Seasonal delimitations were 
established according to their astronomical definition (March 21st, June 21st, September 21st and December 21st) since they fit the seasonal fluctuations of soil microclimate conditions.

We used generalized linear models with gamma error distribution to relate soil $\mathrm{CO}_{2}$ efflux to soil temperature, SWC and treatment (stats package ( $\mathrm{R}$ Core Team, 2017)). An individual model was built for each forest to account for differences in the relationships between $\mathrm{R}_{\mathrm{S}}$ components and soil microclimate. We tested two biological responses as a function of soil temperature: (1) an exponential increase in $R_{S}$ components -biological activity increases without any limit-; and (2) a secondorder exponential growth of $R_{S}$ components according to the Gaussian function ( $O^{\prime}$ Connell, 1990) $-\mathrm{R}_{S}$ reaches its maximum at a given temperature, above which it declines with any further increases in soil temperature. We used the logarithmic link function in the models to linearize the exponential relationship between $\mathrm{R}_{S}$ and the independent variables. We included the categorical variable Treatment and its interaction terms with all the independent variables in the model formulations. We fitted additional generalized linear models to examine the potential interactive effects between SWC and soil temperature on $\mathrm{R}_{\mathrm{S}}$ components. We introduced the SWC as either first- or second-order exponential functions. The combination of the two temperature-dependence functions with no effect, a linear effect or a quadratic effect of SWC resulted in six separate fitted models for each forest (Table 3).

In a second step, we compared the performance of the models in terms of the reduction in the corrected Akaike Information Criterion (AICc) (Akaike, 1973; Burnham and Anderson, 2002). The models were selected by calculating the Akaike weights $\left(\mathrm{W}_{\mathrm{AIC}}\right)$ (Johnson and Omland, 2004) based on two sets of candidates (Lellei-Kovács et al., 2016): models that considered only temperature-dependence functions, and the six models together. The confidence set of best candidate models for the observed data included all the models with a $\mathrm{W}_{\text {AIC }}$ within $10 \%$ of the highest. We examined the explained deviance $\left(D^{2}\right)$ and the significance of each fitted coefficient in the model selected. An iterative process of stepwise removal of the least important terms was performed to select the optimal reduced model. The procedure was repeated until only significant coefficients remained in the model (Table 4, p $\leq 0.1$ ). After each step, we inspected the $D^{2}$, the normal probability plot and the residual plot against the predicted values for the fitted models. We also examined the residual variability against the explanatory variables and the plots, and considered them to be a qualitative factor since measurements of soil $\mathrm{CO}_{2}$ efflux were repeated on the same plots throughout the study. Residual heterogeneities were similar between plots in the fitted models, and we therefore assumed that the variation was ecologically irrelevant and do not consider plots as a random factor in the models (Bolker, 2008).

The optimal reduced models were used to estimate daily $\mathbf{R}_{S}$ and $\mathbf{R}_{H}$ for the whole study period (April 2014-April 2017) and thus to correct any possible bias introduced on the measured soil $\mathrm{CO}_{2}$ efflux by the higher SWC in root-exclusion plots. We used the daily average soil temperature (registered with the iButton sensors) and daily SWC (estimated by means of the SWB in Section 2.4) as input data for the models. Daily rates of $R_{A}$ were calculated by subtracting modelled $R_{H}$ from modelled $R_{S}$. We aggregated the daily values of the $R_{S}$ components to obtain cumulative seasonal and cumulative annual estimates, and calculated the average values for each day of the year (DOY: $0-365$ days, $n=3$ growing seasons). We then estimated the mean relative contribution of $R_{H}$ to $R_{S}$ throughout DOYs. We also calculated the turnover rate for the soil $C$ as the annual amount of $R_{H}$ per unit of $C$ stored in the forest floor, plus $0-50 \mathrm{~cm}$ of mineral soil (Metcalfe et al., 2007; Olsen and Van Miegroet, 2010).

Annual and seasonal amounts of $R_{S}, R_{H}$ and $R_{A}$ were tested for differences between tree species using linear models (stats package, $\mathrm{R}$ Core Team, 2017). Linear models were also applied to test for differences in $R_{S}$ components across seasons for each tree species. Normality and homogeneity of residuals for the linear fitted models were checked by the Shapiro-Wilk and Levene test (car package, Fox and Weisberg, 2011) respectively. Multiple comparisons between the means of the factor levels were made using Tukey's post hoc analyses.

All analyses were performed in the statistical platform $\mathrm{R}$ version 3.4.0. (R Core Team, 2017). The ggplot2 package (Wickham, 2009) was used to generate 2D general plots, and 3D plots were created with the lattice package (Sarkar, 2008).

\section{Results}

\subsection{Variability of soil microclimate and soil $\mathrm{CO}_{2}$ efflux throughout the study period}

Soil microclimate variables at the study site showed pronounced seasonal fluctuations typical of the Mediterranean climate (Fig. 1). Measured soil temperature and SWC had opposing seasonal patterns and hence were negatively correlated $(\rho=-0.85$ and $\rho=-0.73$ in Scots pine and Pyrenean oak forests respectively, p-value $<0.001$ ). The SWC in both forests peaked in mid-winter (Fig. 1b), and then underwent a progressive decrease in spring until reaching its minimum value for the year with the onset of the free-rain period in July, when it remained low until October. Soil water content increased progressively with the start of the autumn rainfall until the soil moisture reached the WHC in winter in both forests. Soil temperature increased in spring (Fig. 1a), peaked around July and then gradually decreased in autumn, and remained low all winter. On the study site, annual average soil temperature was $11.8 \pm 0.7^{\circ} \mathrm{C}$ and annual average SWC was $8.2 \pm 1.6 \%$, without any differences between tree species. With regard to seasons, in winter, soil temperature was higher in the pine than in the oak stand, whereas the opposite occurred in spring (Table 2). The SWC during the winter was higher in the oak than in the pine stand (Table 2). The effect of the root-exclusion treatment on the SWC was only significant in the Scots pine forest (Table 2), which showed higher SWCs in trenched plots than in control plots.

Soil respiration rates varied between forest types and showed large seasonal dynamics, from minimum values in winter to maximum values in spring (Fig. 2a). Soil respiration ranged from 49.0 to $494.8 \mathrm{mg} \mathrm{CO}_{2}-\mathrm{C}$ $\mathrm{m}^{-2} \mathrm{~h}^{-1}$ in pine and 35.4 to $572.1 \mathrm{mg} \mathrm{CO} \mathrm{CO}_{2}-\mathrm{C} \mathrm{m}^{-2} \mathrm{~h}^{-1}$ in oak stands. Measured $R_{H}$ showed a similar seasonal pattern to $R_{S}$ with average

Table 2

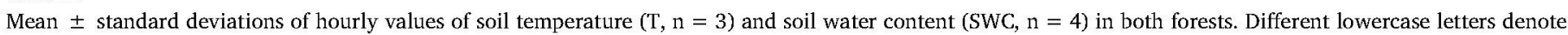

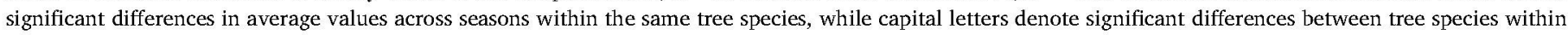

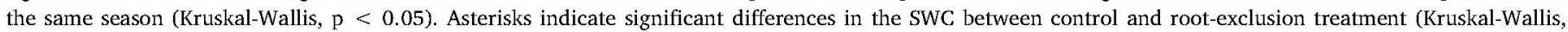
$\mathrm{p}<0.05$ ).

\begin{tabular}{|c|c|c|c|c|c|c|c|c|c|c|c|c|c|c|}
\hline Soil variables & Forest & Treatment & Winter & & & Spring & & & Summer & & & Autumn & & Annual \\
\hline \multirow[t]{2}{*}{$\mathrm{T}\left({ }^{\circ} \mathrm{C}\right)$} & Pine & - & $4.7 \pm 0.9$ & A & d & $11.8 \pm 0.7$ & B & b & $18.4 \pm 1.1$ & & a & $9.8 \pm 0.4$ & c & $11.7 \pm 0.7$ \\
\hline & Oak & - & $3.9 \pm 1.2$ & B & d & $13.3 \pm 0.8$ & A & b & $18.4 \pm 0.6$ & & a & $10.0 \pm 0.5$ & c & $11.9 \pm 0.9$ \\
\hline \multirow[t]{4}{*}{ SWC $(\%)$} & Pine & Control & $11.4 \pm 2.3$ & B & a & $10.6 \pm 3.5$ & & $\mathrm{a}$ & $2.1 \pm 1.0^{*} \mathrm{~b}$ & & & $8.7 \pm 1.7$ & $\mathrm{a}$ & $7.7 \pm 2.1^{*}$ \\
\hline & & Root-exclusion & $12.3 \pm 2.2$ & & a & $12.5 \pm 2.1$ & & $\mathrm{a}$ & $4.5 \pm 0.7^{+}$ & A & c & $9.2 \pm 2.2$ & $\mathrm{~b}$ & $9.3 \pm 1.6^{*}$ \\
\hline & Oak & Control & $13.5 \pm 1.4$ & A & a & $10.2 \pm 1.5$ & & b & $2.7 \pm 0.6$ & & c & $10.3 \pm 0.8$ & $\mathrm{~b}$ & $8.7 \pm 1.0$ \\
\hline & & Root-exclusion & $13.6 \pm 0.4$ & & a & $10.2 \pm 1.9$ & & $\mathrm{~b}$ & $3.3 \pm 1.0$ & B & c & $10.8 \pm 1.1$ & b & $9.0 \pm 1.1$ \\
\hline
\end{tabular}


Table 3

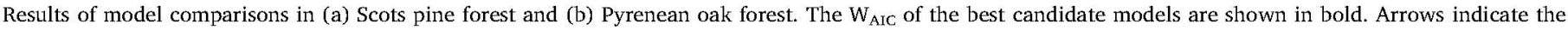

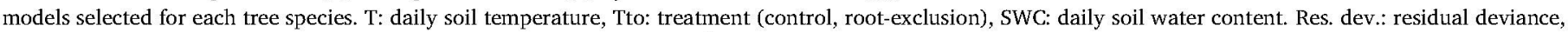
AICc: corrected Akaike information criterion, d.f.: degrees of freedom, $D^{2}$ : deviance explained, $W_{\text {AIC: }}$ Akaike weights.

\begin{tabular}{|c|c|c|c|c|c|c|c|c|}
\hline Tree species & Generalized linear models & & Res. dev. & AICc & d.f. & $\mathrm{D}^{2}(\%)$ & \multicolumn{2}{|c|}{$\mathrm{W}_{\mathrm{AIC}}$} \\
\hline (a) Scots pine & Null $\sim 1$ & & 64.05 & 2830.1 & 254 & & & \\
\hline \multicolumn{9}{|l|}{ SWC is not considered } \\
\hline Linear effect of $\mathrm{T}$ & $\mathrm{T} \times \mathrm{T}$ to & (1) & 52.66 & 2784.4 & 251 & 17.78 & $<0.01$ & $<0.01$ \\
\hline Quadratic effect of $\mathrm{T}$ & $\mathrm{T} \times$ Tto $+\mathrm{T}^{2} \times$ Tto & (2) & 42.97 & 2735.1 & 249 & 32.92 & 1.000 & $<0.01$ \\
\hline \multicolumn{9}{|c|}{ Linear SWC interaction effect } \\
\hline Linear effect of $\mathrm{T}$ & $\mathrm{T} \times \mathrm{T}$ to $\times$ SWC & (3) & 23.47 & 2581.8 & 247 & 63.37 & - & 0.196 \\
\hline Quadratic effect of $\mathrm{T}$ & $\mathrm{T} \times \mathrm{T}$ to $\times \mathrm{SWC}+\mathrm{T}^{2} \times \mathrm{T}$ to $\times \mathrm{SWC}$ & (4) & 22.60 & 2580.5 & 243 & 64.77 & - & 0.391 \\
\hline \multicolumn{9}{|c|}{ Quadratic SWC interaction effect } \\
\hline Linear effect of $\mathrm{T}$ & $\mathrm{T} \times \mathrm{T}$ to $\times \mathrm{SWC}+\mathrm{T} \times \mathrm{T}$ to $\times \mathrm{SWC}^{2}$ & (5) & 22.81 & 2583.2 & 243 & 64.69 & - & 0.099 \\
\hline$\rightarrow$ Quadratic effect of $\mathrm{T}$ & $\mathrm{T} \times \mathrm{T}$ to $\times \mathrm{SWC}+\mathrm{T}^{2} \times \mathrm{T}$ to $\times \mathrm{SWC}+\mathrm{T} \times \mathrm{T}$ to $\times \mathrm{SWC}^{2}+\mathrm{T}^{2} \times \mathrm{T}$ to $\times \mathrm{SWC}^{2}$ & (6) & 21.45 & 2580.9 & 237 & 66.51 & - & 0.314 \\
\hline (b) Pyrenean oak & Null $\sim 1$ & & 82.83 & 3081.7 & 278 & & & \\
\hline \multicolumn{9}{|l|}{ SWC is not considered } \\
\hline Linear effect of $\mathrm{T}$ & $\mathrm{T} \times \mathrm{T}$ to & (1) & 62.88 & 3007.7 & 275 & 24.08 & $<0.01$ & $<0.01$ \\
\hline Quadratic effect of $\mathrm{T}$ & $\mathrm{T} \times \mathrm{T}$ to $+\mathrm{T}^{2} \times \mathrm{T}$ to & (2) & 45.11 & 2916.2 & 273 & 45.54 & 1.000 & $<0.01$ \\
\hline \multicolumn{9}{|c|}{ Linear SWC interaction effect } \\
\hline Linear effect of $T$ & $\mathrm{~T} \times \mathrm{T}$ to $\times \mathrm{SWC}$ & $(3)$ & 35.44 & 2851.6 & 271 & 57.21 & - & $<0.01$ \\
\hline$\rightarrow$ Quadratic effect of $\mathrm{T}$ & $\mathrm{T} \times \mathrm{T}$ to $\times \mathrm{SWC}+\mathrm{T}^{2} \times \mathrm{T}$ to $\times \mathrm{SWC}$ & (4) & 29.41 & 2807.1 & 267 & 64.50 & - & 0.997 \\
\hline \multicolumn{9}{|c|}{ Quadratic SWC interaction effect } \\
\hline Linear effect of $\mathrm{T}$ & $\mathrm{T} \times \mathrm{T}$ to $\times \mathrm{SWC}+\mathrm{T} \times \mathrm{T}$ to $\times \mathrm{SWC}^{2}$ & (5) & 32.78 & 2838.0 & 267 & 60.43 & - & $<0.01$ \\
\hline Quadratic effect of $\mathrm{T}$ & $\mathrm{T} \times \mathrm{T}$ to $\times \mathrm{SWC}+\mathrm{T}^{2} \times \mathrm{T}$ to $\times \mathrm{SWC}+\mathrm{T} \times \mathrm{T}$ to $\times \mathrm{SWC}^{2}+\mathrm{T}^{2} \times \mathrm{T}$ to $\times \mathrm{SWC}^{2}$ & (6) & 29.23 & 2818.9 & 261 & 64.71 & - & $<0.01$ \\
\hline
\end{tabular}

values during the measurement period of $138.8 \pm 5.3 \mathrm{mg} \mathrm{CO}_{2}-\mathrm{C}$ $\mathrm{m}^{-2} \mathrm{~h}^{-1}$ in pine and $106.8 \pm 13.5 \mathrm{mg} \mathrm{CO}_{2}-\mathrm{C} \mathrm{m}^{-2} \mathrm{~h}^{-1}$ in oak forests (Fig. 2b)

\subsection{Choosing the statistical model for soil $\mathrm{CO}_{2}$ efflux in each forest}

In both forests, the quadratic temperature dependence of soil $\mathrm{CO}_{2}$ efflux was shown unambiguously to be the model that best fitted the empirical data when considering this climate variable exclusively (Table 3), meaning that increased soil temperatures above an optimum temperature resulted in lower soil $\mathrm{CO}_{2}$ efflux.

The models that included the interactive effects of soil temperature and SWC on soil $\mathrm{CO}_{2}$ efflux greatly improved the quality of fit, as seen from the lower AICc values in comparison with models that do not consider SWC (Table 3). In the Pyrenean oak forest, the model for the interaction effect between linear SWC and quadratic soil temperature (model 4 in Table $3 \mathrm{~b}$ ) unequivocally showed the best fit $\left(\mathrm{W}_{\mathrm{AIC}}>0.99\right.$ ), while in the Scots pine forest all models with interactive SWC effects performed equally, irrespective of the relationship between soil temperature and SWC $\left(\mathrm{W}_{\mathrm{AIC}}>0.01\right)$. In most cases, the model choice strongly affected the predicted values of soil $\mathrm{CO}_{2}$ efflux at the extremes of the ranges of the data set used in the model fitting procedure (BondLamberty et al., 2004a). The values near the range limits of the soil microclimate variables are normally underrepresented in the data and this may hamper the detection of differences in the shape of the model under these circumstances. We chose the model containing the quadratic interaction effect of soil temperature and SWC to explain soil $\mathrm{CO}_{2}$ efflux in pine forests (model 6 in Table 3 a) because it showed the narrowest confidence intervals with the soil at both its WHC in winter and its wilting point in the free-rain period (data not shown).

Optimal reduced models with all terms statistically significant at $\mathrm{p}<0.1$ for Scots pine and Pyrenean oak forests accounted for $64.8 \%$ and $63.7 \%$ of the variability in soil $\mathrm{CO}_{2}$ efflux respectively (Table 4). The main effects of soil temperature explained most of the $\mathrm{D}^{2}$ in the models of both forest stands ( $32.4 \%$ in pine and $31 \%$ in oak). The interaction effects between soil temperature and either SWC or Treatment in the oak stand suggest that optimal temperatures for soil $\mathrm{CO}_{2}$ efflux vary differently with diverse levels of SWC in $R_{H}$ and $R_{A}$ components (Fig. $3 b, d$ and $f$ ). The main effects of SWC explained less $D^{2}$ in the pine
(6.2\%) than in the oak stand (14.7\%). We only found an optimal SWC for soil $\mathrm{CO}_{2}$ efflux in the pine stand, which was also dependent on soil temperature since the interaction effects between both microclimate variables significantly accounted for $2.4 \%$ of the model $\mathrm{D}^{2}$ (Table $4 \mathrm{a}$ ). The SWC sensitivity of soil $\mathrm{CO}_{2}$ efflux varied between treatments in the pine stand (Table 4a), indicating both a restriction of $\mathbf{R}_{\mathbf{H}}$ above the soil WHC (Fig. 3c), and a restriction on $\mathrm{R}_{\mathrm{A}}$ at the soil wilting point (Fig. 3e).

\subsection{Soil respiratory components: anmual and seasonal patterns}

Estimated daily rates of $\mathrm{R}_{\mathrm{A}}$ throughout the study period differed between forest types and underwent strong seasonal fluctuations, revealing marked variations between the forests (Fig. 4). $R_{\mathrm{A}}$ ranged from almost negligible values in both stands to 47.6 and $65.9 \mathrm{mg} \mathrm{CO}_{2}-\mathrm{C}$ $\mathrm{m}^{-2} \mathrm{~h}^{-1}$ in pine and oak respectively. $\mathrm{R}_{\mathrm{H}}$ followed similar patterns in soils from pine and oak stands (Fig. 4) with minimum rates in winter (52.3 and $35.4 \mathrm{mg} \mathrm{CO} \mathrm{C}_{2}-\mathrm{C} \mathrm{m}^{-2} \mathrm{~h}^{-1}$ respectively) and maximum rates in

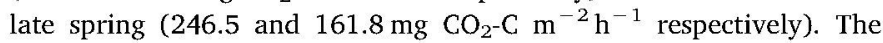
relative contribution of each soil respiratory component to $\mathbf{R}_{S}$ varied throughout the year (Fig. 5). The highest contribution of $\mathbf{R}_{\mathrm{A}}$ to $\mathbf{R}_{\mathrm{S}}$ in the pine forest occurred in the period between mid-October (DOY 281) and end June (DOY 183), while $R_{A}$ had a greater relative importance in the oak forest from April (DOY 83) to October (DOY 330).

For the study period (April 2014-April 2017), annual predicted $R_{S}$ was similar in the Pyrenean oak and Scots pine forests $(\mathrm{p}=0.125$, Table 5). $\mathbf{R}_{\mathrm{A}}$ was significantly higher in the oak than in the pine stand ( $p<0.001$ ), whereas the opposite occurred for $R_{H}$, which showed lower values in the oak than in the pine stand $(\mathrm{p}<0.01)$. However, the $\mathbf{R}_{\mathrm{H}}$ for the stored $\mathrm{C}$ in the soils in the study (Díaz-Pinés et al., 2011b) pointed to a significantly faster turnover rate of soil $\mathrm{C}$ in the oak than in the pine forest ( $p<0.001$ ). On average, $R_{H}$ accounted for $88.2 \%$ of total $R_{S}$ in pine and $75.8 \%$ in oak stands.

\section{Discussion}

\subsection{Modelling soil microclimate control on soil $\mathrm{CO}_{2}$ efflux}

Estimates of annual $\mathrm{R}_{\mathrm{S}}$ in this study were $1.03 \mathrm{~kg} \mathrm{CO}_{2}-\mathrm{C} \mathrm{m}^{-2}$ year $^{-1}$ irrespective of the tree species, which is similar to reported values for 
Table 4

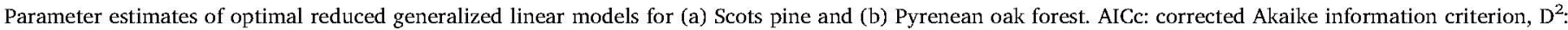

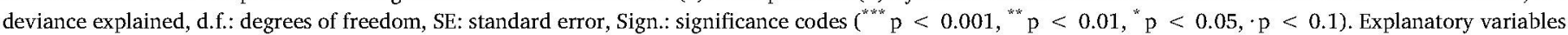
(T: soil temperature, SWC: soil water content).

\begin{tabular}{|c|c|c|c|c|c|c|c|c|}
\hline Terms & AICc & $\mathrm{D}^{2}$ & d.f. & Deviance & Estimate & SE & $\mathrm{t}$-value & Sign. \\
\hline (a) Scots pine model & 2578.3 & 64.79 & 244 & & & & & \\
\hline Intercept & & 0.00 & 254 & 0.00 & 3.25 & $4.10 \cdot 10^{-1}$ & 7.92 & ${ }_{n+*}$ \\
\hline Treatment & & 0.13 & 253 & 0.08 & $-2.11 \cdot 10^{-2}$ & $7.72 \cdot 10^{-2}$ & -0.27 & \\
\hline $\mathrm{T}$ & & 42.17 & 252 & 26.93 & $1.61 \cdot 10^{-1}$ & $5.46 \cdot 10^{-2}$ & 2.95 & +* \\
\hline SWC & & 48.25 & 251 & 3.89 & $1.23 \cdot 10^{-1}$ & $6.79 \cdot 10^{-2}$ & 1.82 & . \\
\hline $\mathrm{T}^{2}$ & & 56.77 & 250 & 5.46 & $-4.85 \cdot 10^{-3}$ & $1.75 \cdot 10^{-3}$ & -2.77 & +* \\
\hline $\mathrm{SWC}^{2}$ & & 60.32 & 249 & 2.27 & $-4.65 \cdot 10^{-3}$ & $3.07 \cdot 10^{-3}$ & -1.51 & \\
\hline SWC $\times$ Treatment & & 60.99 & 248 & 0.43 & & & & \\
\hline SWC $\times$ control & & & & & - & - & - & \\
\hline SWC $\times$ root-exclusion & & & & & $-1.22 \cdot 10^{-2}$ & $7.46 \cdot 10^{-3}$ & -1.63 & . \\
\hline $\mathrm{T} \times \mathrm{SWC}$ & & 63.07 & 247 & 1.33 & $-1.73 \cdot 10^{-2}$ & $1.04 \cdot 10^{-2}$ & -1.67 & . \\
\hline $\mathrm{T}^{2} \times \mathrm{SWC}$ & & 64.14 & 245 & 0.68 & $1.06 \cdot 10^{-3}$ & $4.01 \cdot 10^{-4}$ & 2.64 & ** \\
\hline $\mathrm{T} \times \mathrm{SWC}^{2}$ & & 64.16 & 245 & 0.02 & $1.01 \cdot 10^{-3}$ & $5.52 \cdot 10^{-4}$ & 1.83 & . \\
\hline $\mathrm{T}^{2} \times \mathrm{SWC}^{2}$ & & 64.79 & 244 & 0.40 & $-5.18 \cdot 10^{-5}$ & $2.53 \cdot 10^{-5}$ & -2.05 & * \\
\hline (b) Pyrenean oak model & 2804.76 & 63.72 & 271 & & & & & \\
\hline Intercept & & 0.00 & 278 & 0.00 & 2.81 & $1.71 \cdot 10^{-1}$ & 16.42 & t** \\
\hline Treatment & & 7.36 & 277 & 6.10 & $8.14 \cdot 10^{-2}$ & $1.48 \cdot 10^{-1}$ & 0.55 & \\
\hline $\mathrm{T}$ & & 23.71 & 276 & 13.54 & $2.24 \cdot 10^{-1}$ & $2.38 \cdot 10^{-2}$ & 9.41 & $* \star *$ \\
\hline SWC & & 41.41 & 275 & 14.66 & $4.40 \cdot 10^{-2}$ & $6.64 \cdot 10^{-3}$ & 6.63 & $* * *$ \\
\hline $\mathrm{T}^{2}$ & & 62.49 & 274 & 17.46 & $-6.21 \cdot 10^{-3}$ & $8.74 \cdot 10^{-4}$ & -7.11 & ${ }^{* * *}$ \\
\hline $\mathrm{T} \times$ Treatment & & 62.89 & 273 & 0.33 & & & & \\
\hline $\mathrm{T} \times$ control & & & & & - & - & - & \\
\hline $\mathrm{T} \times$ root-exclusion & & & & & $-5.68 \cdot 10^{-2}$ & $2.66 \cdot 10^{-2}$ & -2.13 & + \\
\hline $\mathrm{T}^{2} \times$ Treatment & & 63.38 & 272 & 0.41 & & & & \\
\hline $\mathrm{T}^{2} \times$ control & & & & & - & - & - & \\
\hline $\mathrm{T}^{2} \times$ root-exclusion & & & & & $1.90 \cdot 10^{-3}$ & $1.05 \cdot 10^{-3}$ & 1.81 & . \\
\hline $\mathrm{T}^{2} \times \mathrm{SWC}$ & & 63.72 & 271 & 0.28 & $5.30 \cdot 10^{-5}$ & $3.29 \cdot 10^{-5}$ & 1.61 & . \\
\hline
\end{tabular}

other pine and oak forests in the Mediterranean basin (Barba et al., 2016; Rey et al., 2002). However, our results clearly showed that tree species largely controlled the temporal dynamics of the soil $\mathrm{CO}_{2}$ efflux in the ecotone through specific responses of $R_{A}$ and $R_{H}$ to soil microclimate conditions. We were also able to detect common patterns in the response of $\mathrm{CO}_{2}$ efflux to the environmental conditions, which can be attributed to the particular climate characteristics of the Mediterranean region. Soil temperature in both forests was largely the best predictor of soil $\mathrm{CO}_{2}$ efflux; however the inclusion of the soil temperature-SWC covariation critically improved our modelling capability in this drought-prone ecotone.

Independently of the tree species, a strong seasonality of modelled $\mathrm{R}_{\mathrm{S}}$ was observed, suggesting an apparent limitation to soil metabolic activity all year round except in spring, the only period when optimal soil temperatures and SWC occur simultaneously. The pattern observed in $R_{S}$ may be basically explained by the temporal variability of $R_{H}$, since it accounted for more than $70 \%$ of the total Rs in both forest stands. We also observed peaks of modelled $\mathrm{R}_{\mathrm{H}}$ in autumn produced by occasional rainfall events at the beginning of the wet season (Almagro et al., 2009), when temperatures are still warm. This seasonal pattern for $\mathbf{R}_{\mathrm{H}}$ in our study has been previously reported in other forests in the Mediterranean basin (Chang et al., 2014; Lellei-Kovács et al., 2016; Rey et al., 2002; Tedeschi et al., 2006). We identified low winter temperatures and low summer SWCs as important climate constraints that dampen the apparent temperature sensitivity of $R_{H}$ and other factors that stimulate microbial decomposition, such as the timing of leaf and needle fall when there is an extra input of fresh organic matter (Saiz et al., 2007) and/or high-quality litter (Raich and Tufekcioglu, 2000).

Our results also suggest a higher sensitivity of $R_{A}$ to low values of SWC in pine stands, which agrees with the known vulnerability of Scots pine to drought events (Sabaté et al., 2002; Vayreda et al., 2012). The low SWC values observed here are probably a combined result of the strong seasonality of the precipitation and the low WHC of these coarsetextured soils. High sand contents are common in large areas of the Iberian Peninsula (Ballabio et al., 2016) so we presume these respiratory patterns are occurring in other Scots pine and Pyrenean oak forests. However, additional case studies specifically addressing a broad range of soil textures are highly recommended to assess the extent of the effects of drought on $R_{A}$ and $R_{H}$ at the regional level.

\subsection{Seasonal patterns of soil respiration components modulated by tree species composition}

Although annual $\mathrm{R}_{\mathrm{A}}$ made a modest contribution to total soil $\mathrm{CO}_{2}$ efflux in our study (12-24\%), the differences in this component likely balanced out those of $R_{H}$, so similar annual $R_{S}$ were found in both forest types. Two mechanisms are proposed to explain these differences in $R_{A}$ : (1) the different root-to-shoot ratios derived from historical management (0.54-0.96 in Pyrenean oak coppices (Salomón et al., 2016a) vs 0.28 in Scots pine forests (Ruiz-Peinado et al., 2011)); and (2) the fact that physiological activity (including roots) is more severely constrained in pine than oak during the dry season, resulting in higher $\mathrm{R}_{\mathrm{A}}$ rates in the Pyrenean oak stands. The $R_{A}$ accounted for $24 \%$ of $R_{S}$ in the Pyrenean oak forest, similar to other oak coppices under a Mediterranean climate (Rey et al., 2002; Tedeschi et al., 2006). The $12 \%$ annual contribution of $R_{A}$ to $R_{S}$ in Scots pine is also similar to data from old conifer stands in boreal forests (Bond-Lamberty et al., 2004a), but considerably lower than the $36 \%$ contribution reported for Scots pine suffering die-off on the north-eastern Iberian Peninsula (Barba et al., 2016), or estimates from warm temperate forests (Bond-Lamberty et al., $2004 \mathrm{~b}$ ). The $\mathrm{R}_{\mathrm{A}}$ contribution in both forests falls within the lowest values reported in previous research, which varied from $10 \%$ to $90 \%$ across vegetation types according to Hanson et al. (2000). To the best of our knowledge, our results for pine are among the lowest estimates in forest ecosystems, which may be due to the low volumetric SWCs (rarely above $14 \%$ ) which appear to have a more marked effect on $\mathbf{R}_{\mathrm{A}}$ than on $\mathbf{R}_{\mathrm{H}}$.

The seasonal patterns for $\mathrm{R}_{\mathrm{A}}$ were also significantly different depending on tree species. Water availability has been reported in previous research as a limiting resource for Scots pine growth in 

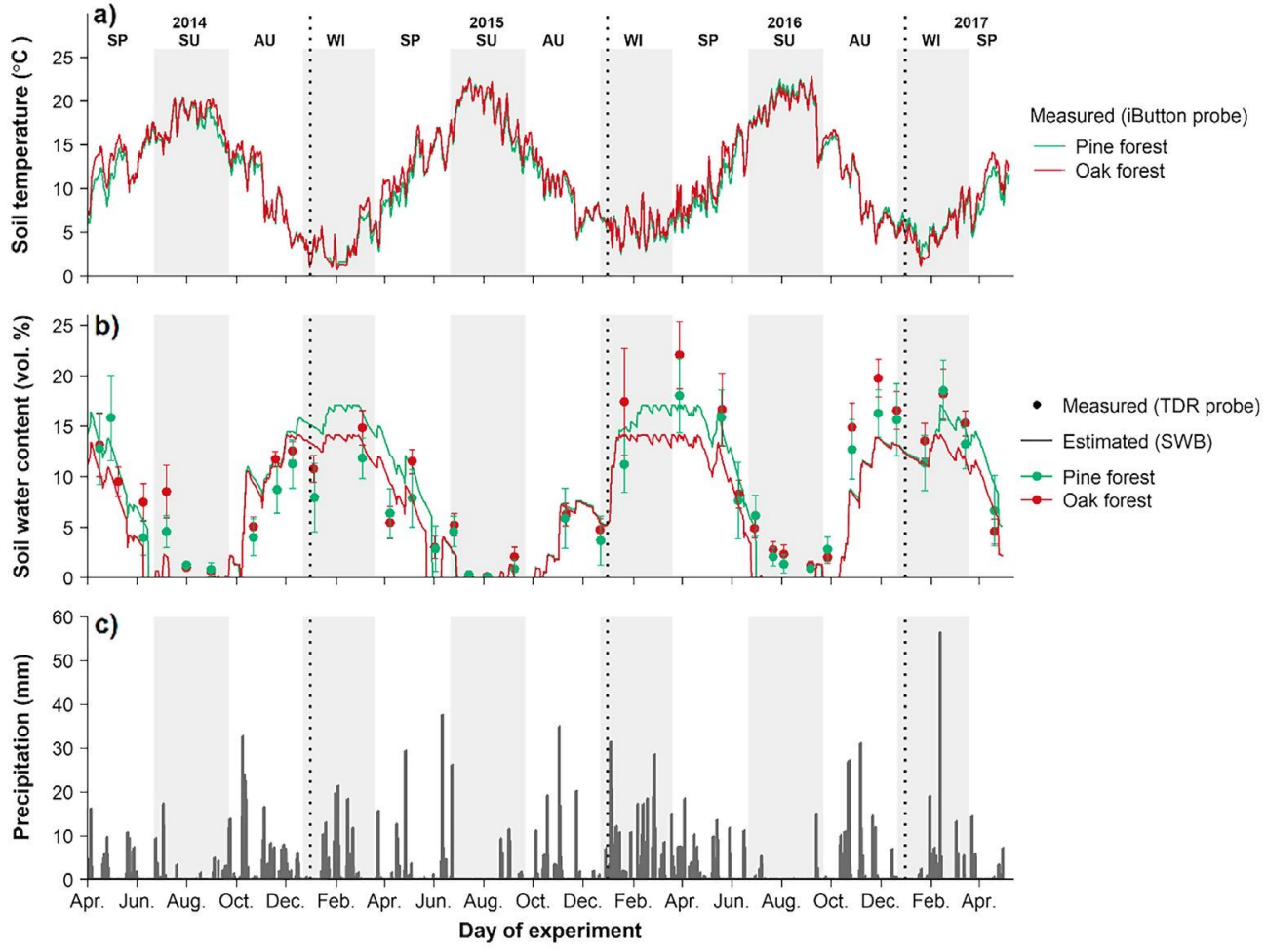

Fig. 1. Seasonal evolution (SP: spring, SU: summer, AU: autumn and WI: winter) of environmental variables throughout the study period (Abril 2014-April 2017). (a) Daily soil temperature (average values for each forest stand from data collected with iButton sensors at $10 \mathrm{~cm}$ in the mineral soil, $\mathrm{n}=3$ ). (b) Daily soil water content (points represent average values $(n=4)$ for each forest stand with bars indicating standard deviation from data collected with a TDR probe at control plots during measurement campaigns; lines represent daily estimated values from soil water balances (SWB)). (c) Daily precipitation (registered in the nearby weather station, Embalse del Pontón Alto).
Mediterranean climates, mainly at its lowest elevations (Bogino et al., 2009; Camarero et al., 2010; Sánchez-Salguero et al., 2015), which is consistent with the pattern of pine $\mathrm{R}_{\mathrm{A}}$ throughout the year. High and sustained $R_{A}$ rates occurred for pine whenever water was available even outside its growing season (Camarero et al., 2010). Rates of $R_{A}$ in winter declined by only $20 \%$ compared to rates in spring, probably because winter photosynthesis enables the pine to produce and accumulate carbohydrates during this unfavourable season (SánchezSalguero et al., 2015). Since SWC in winter was close to WHC, the soil temperature was the constraining factor for pine physiological activity as shown by the $\mathrm{R}_{\mathrm{A}}$. Warm winters therefore appeared to promote higher rates of root physiological activity, and presumably have a positive effect on pine growth (Bogino et al., 2009). In early spring the warmer temperatures and high SWCs resulted in maximum rates of $R_{A}$, coinciding with the resumption of growth in the pines (Camarero et al., 2010). The seasonal trend in $R_{A}$ then reached a turning point and showed minimum rates in summer, a period with overlapping soil water deficit and high evaporative demand. These minimum $R_{\mathrm{A}}$ rates are consistent with other ecophysiological responses observed in pine trees under summer drought, such as efficient stomatal closure to reduce
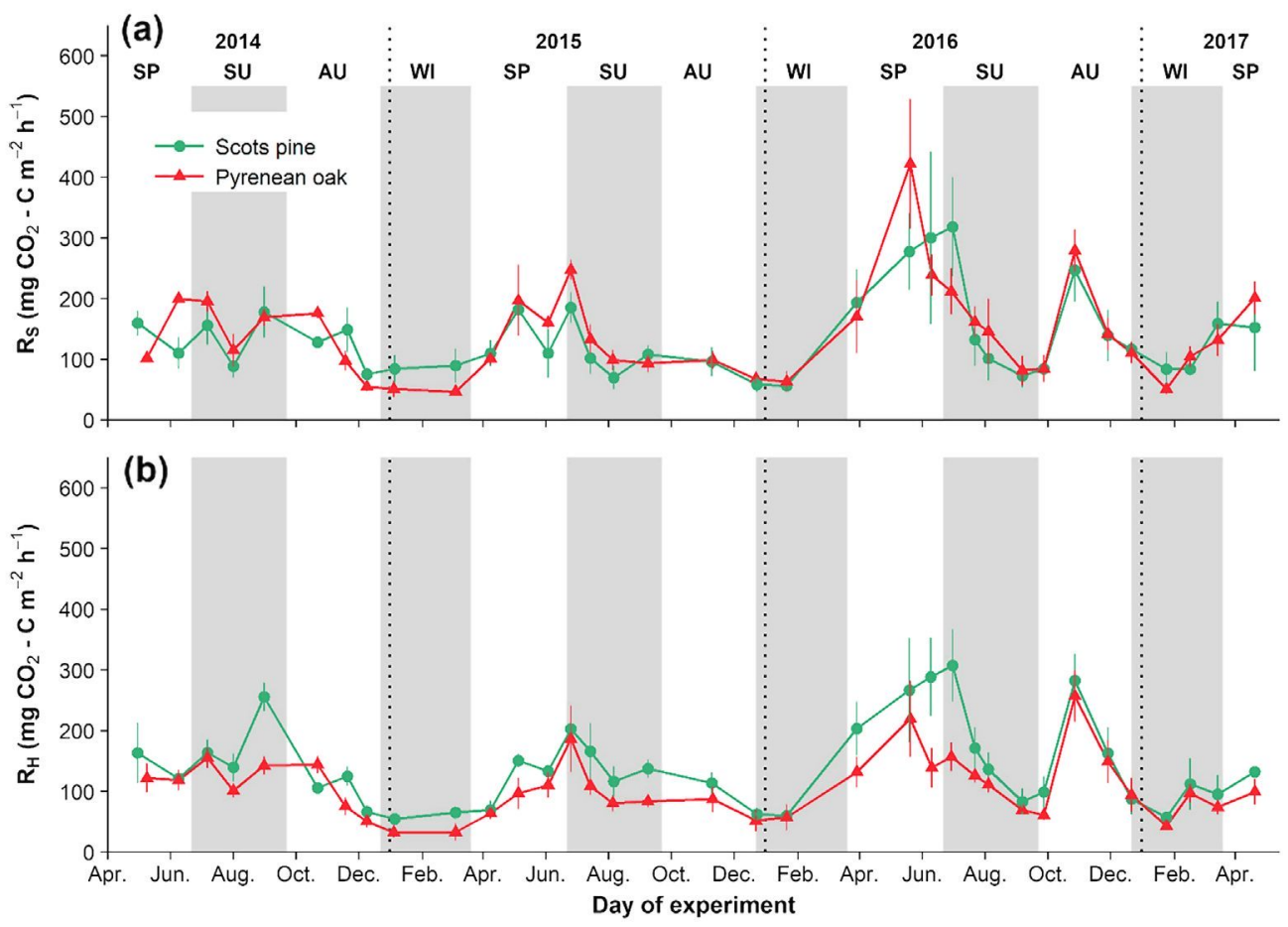

Fig. 2. Soil $\mathrm{CO}_{2}$ efflux measured over the 35 measurement campaigns in (a) the control plots ( $\mathrm{R}_{\mathrm{S}}$ : total soil respiration); and (b) the plots with root-exclusion treatment $\left(\mathrm{R}_{\mathrm{H}}\right.$ : heterotrophic respiration) under Scots pine (green circle) and Pyrenean oak cover (red triangle). Data are mean values of plots with bars representing standard deviation $(n=4)$. SP: spring, SU: summer, AU: attumn and WI: winter. (For interpretation of the references to color in this figure legend, the reader is referred to the web version of this article.) 

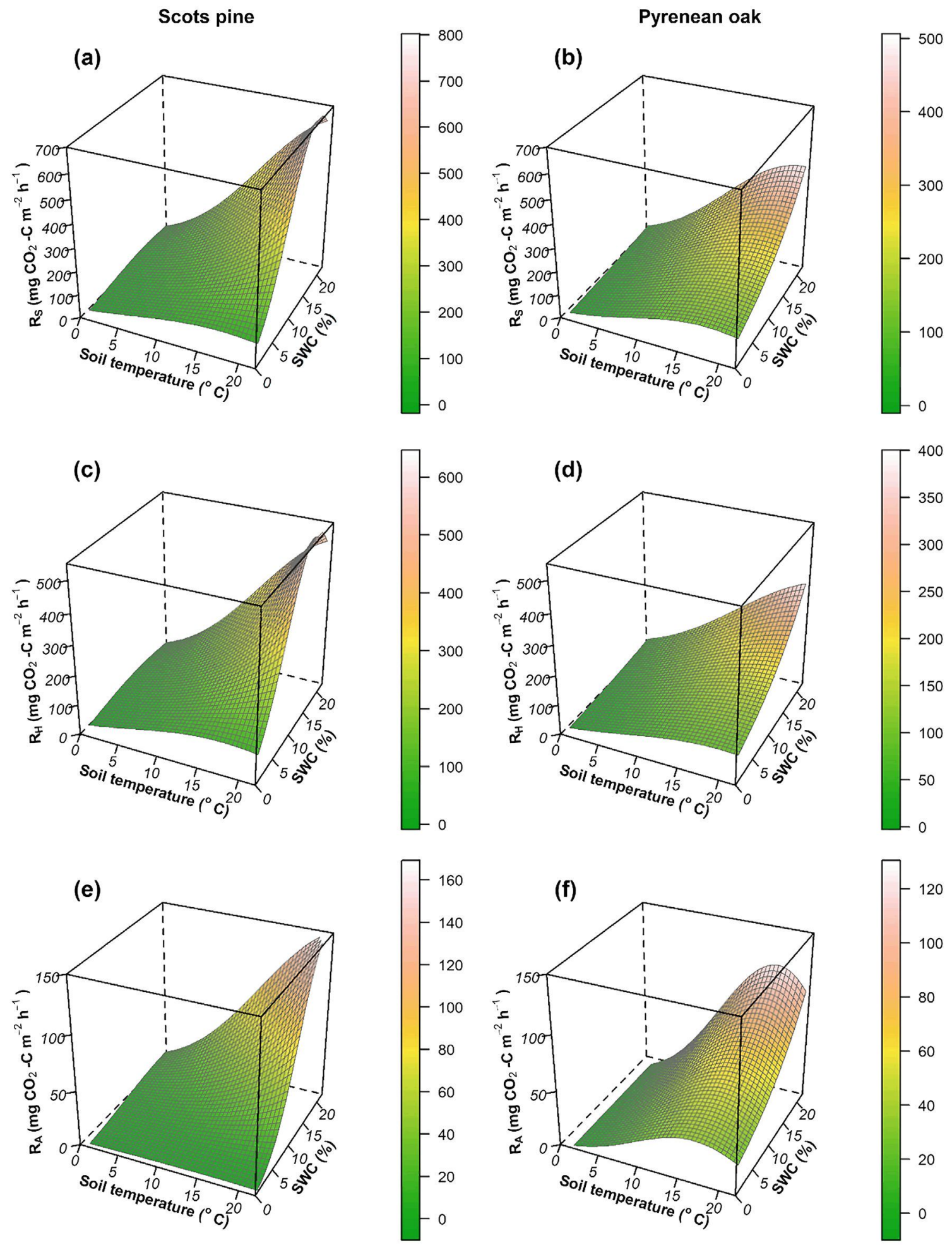

Fig. 3. Modelled response of soil $\mathrm{CO}_{2}$ efflux ( $\mathrm{R}_{\mathrm{S}}$ : total soil respiration, $\mathrm{R}_{\mathrm{H}}$ : heterotrophic respiration, $\mathrm{R}_{\mathrm{A}}$ : autotrophic respiration) to the continuous interaction effect between soil temperature and soil water content (SWC) in Scots pine (a, c, e, respectively) and Pyrenean oak forests (b, d, f, respectively), according to the fitted models in Table 4.

transpiration (Poyatos et al., 2005), low growth rates (Camarero et al., 2010; Sabaté et al., 2002; Vayreda et al., 2012) and needle fall period from May to September (Díaz-Pinés et al., 2011a). The abundant precipitation in the first half of the year may delay the time at which drought stress becomes critical in the pine growing season. Soil temperature throughout winter and soil water availability throughout summer therefore constitute the main limitations for $\mathrm{R}_{\mathrm{A}}$ in Scots pine, closely linked to the main climate constraining factors for pine radial growth (Sánchez-Salguero et al., 2015).

The Pyrenean oak stand showed a distinct temporal evolution of $\mathbf{R}_{\mathrm{A}}$ throughout the year, which we assume can be attributed to different leaf strategies influencing root phenological patterns (Curiel Yuste et al., 2004). Thus the lowest rates of $R_{A}$ were registered during tree dormancy in winter. In early spring, with increasing soil temperatures 


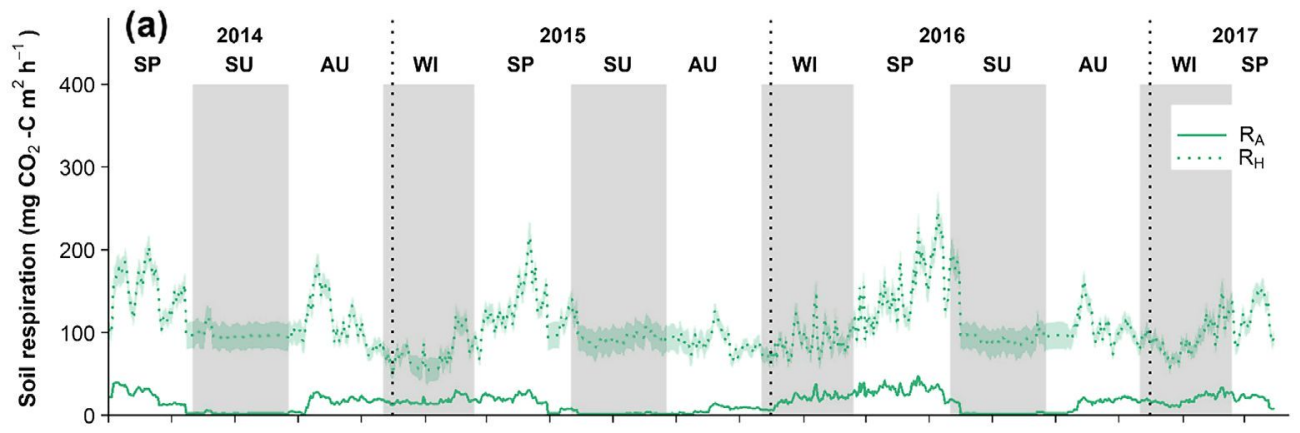

Fig. 4. Modelled daily rates of heterotrophic respiration $\left(\mathrm{R}_{\mathrm{H}}\right)$ according to the parameterized models in Table 4; and estimated daily rates of autotrophic respiration $\left(R_{A}\right)$ as the difference between modelled $R_{S}$ and $R_{H}$ in Scots pine (a) and Pyrenean oak forest (b). Lines represent mean values, and ribbons show the upper and lower 95\% confidence intervals predicted by the models. SP: spring, SU: summer, AU: autumn and WI: winter
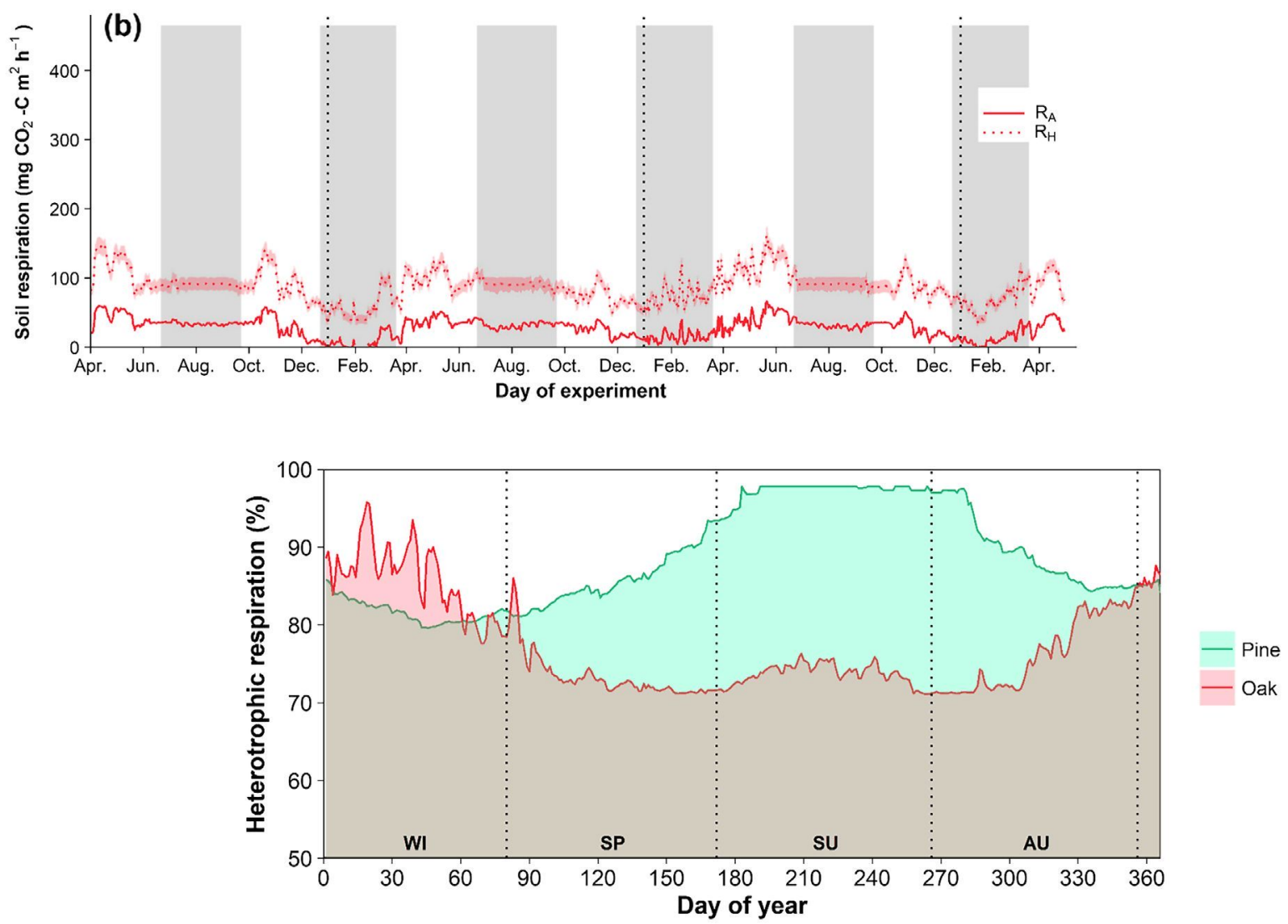

Fig. 5. Relative contribution of soil heterotrophic respiration to total soil respiration under Scots pine and Pyrenean oak tree species. Lines represent daily means of predicted values for the study period (April 2014 to April 2017, $\mathrm{n}=3$ growing seasons). WI: winter, SP: spring, SU: summer and AU: autumn.

and optimum soil moisture conditions, we found a progressive rise in $\mathrm{R}_{\mathrm{A}}$ when the oak became phenologically active (Salomón et al., 2016b). This rise in $\mathrm{R}_{\mathrm{A}}$ peaked roughly three weeks before budburst (bud break occurs around DOY 145), probably fuelled by the mobilization of carbohydrate reserves in roots (Zhu et al., 2012) since there was no fresh assimilation of photosynthates or sap flow before leaf expansion (Salomón et al., 2016b). In June, $\mathrm{R}_{\mathrm{A}}$ contributed up to ca. $30 \%$ to $\mathrm{R}_{\mathrm{S}}$, the highest proportion of the year. This is a time of high metabolic demand for leaf production (Lee et al., 2010) which lasts until photosynthetic activity is reactivated with leaf unfolding. Later in the summer, $\mathbf{R}_{\mathrm{A}}$ rates decreased again across the drought period, which could be explained by the low fine root density and biomass attributed to the depletion of SWC in Mediterranean oak forests (López et al., 1998; Rey et al., 2002). The maximum contribution of $R_{A}$ to $R_{S}$ was again reached in mid-September, coinciding with the decreasing temperatures and the arrival of the autumn rainfall. We registered maintenance $R_{A}$ rates when the oak entered dormancy during its litterfall period from October to December (Díaz-Pinés et al., 2011a).

Differences in $R_{A}$ rates between species may not be completely attributable to plant phenology, since other plant traits and processes may also be involved, such as transport patterns of root-respired $\mathrm{CO}_{2}$ through the xylem, or different physiological strategies to deal with summer drought (Grossiord et al., 2012; Poyatos et al., 2005; Ubierna et al., 2009). We show strong evidence here that SWC and forest functional composition strongly influenced the temperature dependence of $R_{A}$ and thereby $R_{S}$, providing important insights into the possible consequences of changes in forest composition. However, these major differences in $R_{S}$ between oak and pine observed in our study site may have been particularly apparent due to the mild winters favouring Scots pine root activity and the intense summer drought causing evident $R_{A}$ responses. The generalisation of our results should therefore be treated with caution.

\subsection{Soil C stocks and cycling}

Confirming our hypothesis, annual $\mathrm{R}_{\mathrm{H}}$ was highest in the pine stand, where litterfall rates (Díaz-Pinés et al., 2011a) and C stored in the topsoil (Díaz-Pinés et al., 2011b) are significantly higher than in the oak stand. However, the $\mathrm{C}$ turnover rate in soils under pines was roughly twice that of oaks, reflecting the functional traits of leaves and needles 
Table 5

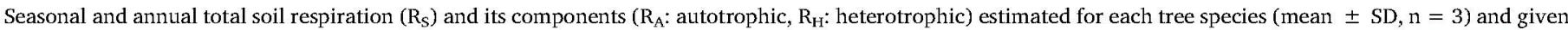

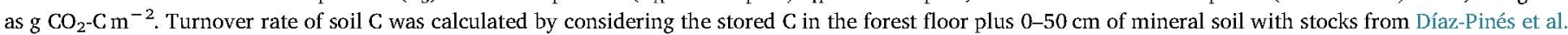

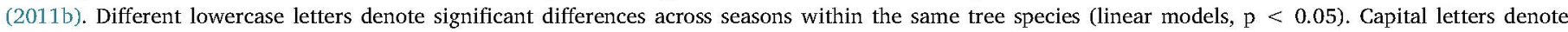
significant differences between tree species within the same period.

\begin{tabular}{|c|c|c|c|c|c|c|c|c|c|c|c|c|c|c|c|c|}
\hline \multirow[t]{2}{*}{ Tree species } & \multirow{2}{*}{$\begin{array}{c}\text { Soil } \mathrm{CO}_{2} \\
\text { efflux }\end{array}$} & \multicolumn{3}{|l|}{ Winter } & \multicolumn{3}{|l|}{ Spring } & \multicolumn{3}{|l|}{ Summer } & \multicolumn{3}{|l|}{ Autumn } & \multirow{2}{*}{\multicolumn{2}{|c|}{$\begin{array}{l}\text { Annual } \\
\left(\mathrm{g} \mathrm{m}^{-2} \text { year }^{-1}\right)\end{array}$}} & \multirow{2}{*}{$\begin{array}{l}\text { Turnover rate } \\
\text { (year }^{-1} \text { ) }\end{array}$} \\
\hline & & \multicolumn{12}{|c|}{$\left(\mathrm{g} \mathrm{m}^{-2}\right.$ season $\left.^{-1}\right)$} & & & \\
\hline \multirow[t]{3}{*}{ Scots pine } & $\mathrm{R}_{\mathrm{S}}$ & $225 \pm 25$ & A & b & $352 \pm 26$ & & a & $229 \pm 9.6$ & B & b & $247 \pm 35$ & & b & $1.05 \cdot 10^{3} \pm 61$ & & \\
\hline & $\mathrm{R}_{\mathrm{A}}$ & $41 \pm 2(18 \%)$ & A & $a b$ & $50 \pm 8(14 \%)$ & B & $\mathrm{a}$ & $7 \pm 1.9(3 \%)$ & B & c & $27 \pm 11(11 \%)$ & B & $\mathrm{b}$ & $124 \pm 13(12 \%)$ & $B$ & \\
\hline & $\mathrm{R}_{\mathrm{H}}$ & $184 \pm 23(82 \%)$ & & b & $302 \pm 18(86 \%)$ & A & a & $222 \pm 7.8(97 \%)$ & A & $\mathrm{b}$ & $220 \pm 25(89 \%)$ & & $\mathrm{b}$ & $929 \pm 48(88 \%)$ & A & $0.10 \pm 0.01$ \\
\hline \multirow[t]{3}{*}{ Pyrenean oak } & $\mathrm{R}_{\mathrm{S}}$ & $167 \pm 23$ & B & & $\mathrm{c} 313 \pm 18$ & & $a$ & $280 \pm 2.3$ & A & $\mathrm{ab}$ & $243 \pm 23$ & & $\mathrm{~b}$ & $1.00 \cdot 10^{3} \pm 29$ & & \\
\hline & $\mathrm{R}_{\mathrm{A}}$ & $25 \pm 8(15 \%)$ & B & $\mathrm{c}$ & $84 \pm 6(27 \%)$ & A & $\mathrm{a}$ & $74 \pm 3.0(26 \%)$ & A & $\mathrm{ab}$ & $60 \pm 5(25 \%)$ & A & $\mathrm{b}$ & $243 \pm 7(24 \%)$ & A & \\
\hline & $\mathrm{R}_{\mathrm{H}}$ & $142 \pm 15(85 \%)$ & & c & $229 \pm 13(73 \%)$ & B & a & $206 \pm 0.9(74 \%)$ & B & $a b$ & $183 \pm 19(75 \%)$ & & $\mathrm{b}$ & $761 \pm 22(76 \%)$ & $\mathrm{B}$ & $0.19 \pm 0.01$ \\
\hline
\end{tabular}

-i.e. the nitrogen and lignin content of plant detritus in the litter layer (Gallardo and Merino, 1992; Melillo et al., 1982)- which is closely linked to tree $\mathrm{C}$ and its strategy for obtaining nutrients (Cornwell et al., 2008; Fernández-Alonso et al., 2018). This result contradicts the similarity in the potential decomposability of soil $\mathrm{C}$ between forest types that was found during an incubation experiment using mineral topsoil samples from the same study site (Díaz-Pinés et al., 2014). Some of the multiple factors affecting the apparent decomposability of soil $\mathrm{C}$ in the field and which may lead to differences in the results obtained under controlled conditions include changes in the composition and activity of the soil microbial community throughout the year, the presence of $C$ pools of varying decomposability and physical protection, and the SWB. The lower decomposability of soil organic matter of pine origin may thus have contributed over centuries to the accumulation of greater soil $\mathrm{C}$ stocks than in the oak stand (Curiel Yuste et al., 2005). Our findings suggest that an upward shift by oak in the ecotone, induced by either climate change or forest management, will affect the soil's capacity to store $\mathrm{C}$; however, the magnitude of the impact could be partly offset by a further intensification of soil microclimate constraints for $\mathrm{R}_{\mathrm{H}}-$ i.e. higher temperatures and extended periods of drought, which may in turn slow the decomposition and release of soil $\mathrm{C}$ pools.

\section{Conclusions}

Our results clearly show different seasonal dynamics in soil metabolic activity between Pyrenean oak and Scots pine stands in a Mediterranean mountain area. Common patterns were also detected in the ecotone of both tree species, highlighting how the strong and inverse water and thermal seasonality of the Mediterranean climate constrains both microbial decomposition activity and root respiration. The consideration of the interaction effect between soil temperature and SWC was therefore critical for appropriately modelling the soil $\mathrm{CO}_{2}$ efflux, and enabled us to detect a higher sensitivity of pine $R_{A}$ than oak $\mathrm{R}_{\mathrm{A}}$ to the summer drought period. The slow turnover rate of pine litter compared to oak-derived detritus may also have promoted soil $\mathrm{C}$ accumulation over the centuries. This greater understanding of the plantsoil system in the ecotone offers an insight into patterns that must be taken into account in future forest management. The forest's capacity to store soil $\mathrm{C}$ could be undermined by an oak expansion driven by current changing environmental conditions; however, the magnitude of the impact could be buffered by the further intensification of soil microclimate constraints on $\mathrm{R}_{\mathrm{H}}$.

\section{Acknowledgements}

We are very grateful to Marta Rivas, Sara Pascual, Jefferson A. Campoverde and Sylvia Gareau for their indispensable assistance during the measurement campaigns. We would like to thank the Spanish Meteorological Agency (AEMET) for providing the climate datasets for this study, the Organismo Autónomo de Parques Nacionales for permission to work in this area, and especially the staff of the Sierra de Guadarrama National Park for their help. We also acknowledge the economic support of the REMEDINAL3-CM Project (MAE-2719) of the Madrid Regional Government and the FORADMIT project (AGL201677863-R) of the Spanish Government.

\section{References}

Akaike, H., 1973. Information theory as an extension of the maximum likelihood principle. In: Petrov, B.N., Csaki, F. (Eds.), Second International Symposiumon Information Theory. Akademia Kiado, pp. 267-281. http://doi.org/10.1007/978-14612-1694-0_15.

Allen, C.D., Macalady, A.K., Chenchouni, H., Bachelet, D., McDowell, N., Vennetier, M., Kitzberger, T., Rigling, A., Breshears, D.D., Hogg (Ted), E.H., Gonzalez, P., Fensham, R., Zhang, Z., Castro, J., Demidova, N., Lim, J.H., Allard, G., Running, S.W., Semerci, A., Cobb, N., 2010. A global overview of drought and heat-induced tree mortality reveals emerging climate change risks for forests. For. Ecol. Manage. 259, 660-684. https://doi.org/10.1016/j.foreco. 2009.09.001.

Allen, R.G., Pereira, L.S., Raes, D., Smith, M., 1998. Crop Evapotranspiration Guidelines for Computing Crop Water Requeriments. FAO, Rome, pp. 300.

Almagro, M., López, J., Querejeta, J.I., Martínez-Mena, M., 2009. Temperature dependence of soil $\mathrm{CO}_{2}$ efflux is strongly modulated by seasonal patterns of moisture availability in a Mediterranean ecosystem. Soil Biol. Biochem. 41, 594-605. https:// doi.org/10.1016/j.soilbio.2008.12.021.

Ballabio, C., Panagos, P., Monatanarella, L., 2016. Mapping topsoil physical properties at European scale using the LUCAS database. Geoderma 261, 110-123. https://doi.org/ 10.1016/j.geoderma.2015.07.006.

Barba, J., Curiel Yuste, J., Poyatos, R., Janssens, I.A., Lloret, F., 2016. Strong resilience of soil respiration components to drought-induced die-off resulting in forest secondary succession. Oecologia 1-15. https://doi.org/10.1007/s00442-016-3567-8.

Bardgett, R.D., Wardle, D.A., 2010. Aboveground-belowground Linkages. Biotic Interactions, Ecosystem Processes, and Global Change. Oxford University Press, New York, USA.

Bogino, S., Fernández Nieto, M.J., Bravo, F., 2009. Climate effect on radial growth of pinus sylvestris at its southern and western distribution limits. Silva Fennica 43, $609-623$.

Bolker, B.M., 2008. Ecological Models and Data in R. Princenton University Press, New Jersey.

Bond-Lamberty, B., Wang, C., Gower, S.T., 2004a. Contribution of root respiration to soil surface $\mathrm{CO}_{2}$ flux in a boreal black spruce chronosequence. Tree Physiol. 24, 1387-1395. https://doi.org/10.1093/treephys/24.12.1387.

Bond-Lamberty, B., Wang, C., Gower, S.T., 2004b. A global relationship between the heterotrophic and autotrophic components of soil respiration? Glob. Change Biol. 10 1756-1766. https://doi.org/10.1111/j.1365-2486.2004.00816.x.

Botey, M.R., Pérez-Arias, J., Moreno, J.V., 2011. Estimación del contenido de agua del suelo mediante el balance hídrico exponencial diario y comparación con medidas in situ en un typic Haploxeralf en la zona centro (Madrid - España). In: Martínez Fernández, J., Sánchez Martín, N. (Eds.), Actas de Las X Jornadas de Investigación de La Zona No Saturada Del Suelo. Salamanca, pp. 217-222. http://doi.org/10.1109/ TGRS.2011.2120615.

Burnham, K.P., Anderson, D., 2002. Model Selection and Multimodel Inference: A Practical Information-theoretic Approach. Springer-Verlag, New York.

Butler, A., Meir, P., Saiz, G., Maracahipes, L., Marimon, B.S., Grace, J., 2012. Annual variation in soil respiration and its component parts in two structurally contrasting woody savannas in Central Brazil. Plant Soil 352, 129-142. https://doi.org/10.1007/ s11104-011-0984-7.

Camarero, J.J., Olano, J.M., Parras, A., 2010. Plastic bimodal xylogenesis in conifers from continental Mediterranean climates. New Phytol. 185, 471-480. https://doi.org/10. 1111/j.1469-8137.2009.03073.x.

Chang, C.T., Sabaté, S., Sperlich, D., Poblador, S., Sabater, F., Gracia, C., 2014. Does soil moisture overrule temperature dependency of soil respiration in Mediterranean riparian forests? Biogeosciences 11,6173-6185. https://doi.org/10.5194/bgd-117991-2014. 
Cornwell, W.K., Cornelissen, J.H.C., Amatangelo, K., Dorrepaal, E., Eviner, V.T., Godoy, O., Hobbie, S.E., Hoorens, B., Kurokawa, H., Pérez-Harguindeguy, N., Quested, H.M., Santiago, L.S., Wardle, D.A., Wright, I.J., Aerts, R., Allison, S.D., Van Bodegom, P., Brovkin, V., Chatain, A., Callaghan, T.V., Díaz, S., Garnier, E., Gurvich, D.E. Kazakou, E., Klein, J.A., Read, J., Reich, P.B., Soudzilovskaia, N.A., Vaieretti, M.V., Westoby, M., 2008. Plant species traits are the predominant control on litter decomposition rates within biomes worldwide. Ecol. Lett. 11, 1065-1071. https://doi. org/10.1111/j.1461-0248.2008.01219.x.

Curiel Yuste, J., Janssens, I.A., Carrara, A., Ceulemans, R., 2004. Annual $Q_{10}$ of soil respiration reflects plant phenological patterns as well as temperature sensitivity. Glob. Change Biol. 10, 161-169. https://doi.org/10.1111/j.1529-8817.2003.00727.x.

Curiel Yuste, J., Konôpka, B., Janssens, I.A., Coenen, K., Xiao, C.W., Ceulemans, R., 2005. Contrasting net primary productivity and carbon distribution between neighboring stands of Quercus robur and Pinus sylvestris. Tree physiol. 25, 701-712. https://doi. org/10.1093/treephys/25.6.701.

Davidson, E.A., Janssens, I.A., 2006. Temperature sensitivity of soil carbon decomposition and feedbacks to climate change. Nature 440, 165-173. https://doi.org/10. 1038/nature04514.

Díaz-Pinés, E., Rubio, A., Montes, F., 201la. Aboveground soil C inputs in the ecotone between Scots pine and Pyrenean oak in Sierra de Guadarrama. For. Syst. 20 485-495. https://doi.org/10.5424/fs/20112003-11083.

Díaz-Pinés, E., Rubio, A., Van Miegroet, H., Montes, F., Benito, M., 2011b. Does tree species composition control soil organic carbon pools in Mediterranean mountain forests? For. Ecol. Manage. 262, 1895-1904. https://doi.org/10.1016/j.foreco. 2011. 02.004 .

Díaz-Pinés, E., Schindlbacher, A., Godino, M., Kitzler, B., Jandl, R., ZechmeisterBoltenstern, S., Rubio, A., 2014. Effects of tree species composition on the $\mathrm{CO}_{2}$ and $\mathrm{N}_{2} \mathrm{O}$ efflux of a Mediterranean mountain forest soil. Plant Soil 384, 243-257. https:// doi.org/10.1007/s11104-014-2200-z.

Díaz-Pinés, E., Schindlbacher, A., Pfeffer, M., Jandl, R., Zechmeister-Boltenstern, S., Rubio, A., 2010. Root trenching: a useful tool to estimate autotrophic soil respiration? A case study in an Austrian mountain forest. Eur. J. Forest Res. 129, 101-109. https://doi.org/10.1007/s10342-008-0250-6.

Domingo, J.M., Fernández De Villarán, R., Corral, E., Rapp, I., 2006. Estimación de la capacidad de retención de agua en el suelo: revisión del parámetro CRA. Investigación agraria. Sistemas y recursos forestales 15, 14-23.

Ewel, K.C., Cropper, W.P., Gholz, H.L., 1987. Soil $\mathrm{CO}_{2}$ evolution in Florida slash pine plantations. II. Importance of root respiration. Can. J. For. Res. 17, 330-333.

Fang, C., Moncrieff, J.B., 2001. The dependence of soil $\mathrm{CO}_{2}$ efflux on temperature. Soil Biol. Biochem. 33, 155-165. https://doi.org/10.1016/S0038-0717(00)00125-5.

Fernández-Alonso, M.J., Curiel Yuste, J., Kitzler, B., Ortiz, C., Rubio, A., 2018. Changes in litter chemistry associated with global change-driven forest succession resulted in time-decoupled responses of soil carbon and nitrogen cycles. Soil Biol. Biochem. 120, 200-211. https://doi.org/10.1016/j. soilbio.2018.02.013.

Fox, J., Weisberg, S., 2011. An R Companion to Applied Regression. SAGE, Thousand Oaks, California.

Galiano, L., Martínez-Vilalta, J., Lloret, F., 2010. Drought-induced multifactor decline of Scots pine in the Pyrenees and potential vegetation change by the expansion of cooccurring oak species. Ecosystems 13, 978-991. https://doi.org/10.1007/s10021010-9368-8.

Galiano, L., Martínez-Vilalta, J., Lloret, F., 2011. Carbon reserves and canopy defoliation determine the recovery of Scots pine $4 \mathrm{yr}$ after a drought episode. New Phytol. 190, 750-759. https://doi.org/10.1111/j.1469-8137.2010.03628.x.

Gallardo, A., Merino, J., 1992. Nitrogen immobilization in leaf litter at two Mediterranean ecosystems of SW Spain. Biogeochemistry 15, 213-228.

Gandullo, J.M., 1994. Climatología y ciencia del suelo. Fundación Conde del Valle de Salazar ETSI Montes, Madrid.

Goulden, M.L., Munger, J.W., Fan, S.-M., Daube, B.C., Wofsy, S.C., 1996. Exchange of carbon dioxide by a deciduous forest: response to interannual climate variability. Science 271, 1576-1578. https://doi.org/10.1126/science.271.5255.1576.

Grossiord, C., Mareschal, L., Epron, D., 2012. Transpiration alters the contribution of autotrophic and heterotrophic components of soil $\mathrm{CO}_{2}$ efflux. New Phytol. 194, 647-653. https://doi.org/10.1111/j.1469-8137.2012.04102.x.

Hanson, P.J., Edwards, N.T., Garten, C.T., Andrews, J.A., 2000. Separating root and soil microbial contributions to soil respiration: a review of methods and observations. Biogeochemistry 48, 115-146. https://doi.org/10.1023/A:1006244819642.

Högberg, P., Nordgren, A., Buchmann, N., Taylor, A.F., Ekblad, A., Högberg, M.N., Nyberg, G., Ottosson-Löfvenius, M., Read, D.J., 2001. Large-scale forest girdling shows that current photosynthesis drives soil respiration. Nature 411, 789-792. https://doi.org/10.1038/35081058.

Hutchinson, G.L., Livingston, G.P., 2001. Vents and seals in non-steady-state chambers used for measuring gas exchange between soil and the atmosphere. Eur. J. Soil Sci. 52, 675-682. https://doi.org/10.1046/j.1365-2389.2001.00415.x.

Johnson, J.B., Omland, K.S., 2004. Model selection in ecology and evolution. Trends Ecol. Evol. 19, 101-108. https://doi.org/10.1016/j.tree.2003.10.013.

Kirschbaum, M.U.F.F., 1995. The temperature dependence of soil organic matter decomposition, and the effect of global warming on soil organic C storage. Soil Biol. Biochem. 27, 753-760. https://doi.org/10.1016/0038-0717(94)00242-S.

Kuzyakov, Y., 2006. Sources of $\mathrm{CO}_{2}$ efflux from soil and review of partitioning methods. Soil Biol. Biochem. 38, 425-448. https://doi.org/10.1016/j.soilbio.2005.08.020.

Lee, N., Yeon, Koo, J.W., Noh, N.J., Kim, J., Son, Y., 2010. Seasonal variation in soil $\mathrm{CO}_{2}$ efflux in evergreen coniferous and broad-leaved deciduous forests in a cool-temperate forest, central Korea. Ecol. Res. 25, 609-617. https://doi.org/10.1007/s11284-0100691-5.

Lellei-Kovács, E., Botta-Dukát, Z., de Dato, G., Estiarte, M., Guidolotti, G., Kopittke, G.R., Kovács-Láng, E., Kröel-Dulay, G., Larsen, K.S., Peñuelas, J., Smith, A.R., Sowerby, A.,
Tietema, A., Schmidt, I.K., 2016. Temperature dependence of soil respiration modulated by thresholds in soil water availability across european shrubland ecosystems. Ecosystems 19, 1460-1477. https://doi.org/10.1007/s10021-016-0016-9.

López, B., Sabaté, S., Gracia, C., 1998. Fine roots dynamics in a Mediterranean forest: effects of drought and stem density. Tree Physiol. 18, 601-606. https://doi.org/10. 1093/treephys/18.8-9.601.

Manzoni, S., Schaeffer, S.M., Katul, G., Porporato, A., Schimel, J.P., 2014. A theoretical analysis of microbial eco-physiological and diffusion limitations to carbon cycling in drying soils. Soil Biol. Biochem. 73, 69-83. https://doi.org/10.1016/j.soilbio.2014. 02.008 .

Martínez-Vilalta, J., Piñol, J., 2002. Drought-induced mortality and hydraulic architecture in pine populations of the NE Iberian Peninsula. For. Ecol. Manage. 161, 247-256. https://doi.org/10,1016/S0378-1127(01)00495-9.

Martínez García, F., Montero, G., 2000. Typology of Pinus sylvestris L. forest in Spain. Investigación Agraria, Sistemas y Recursos Forestales: Fuera de serie, no 1, 41-65.

Melillo, J.M., Aber, J.D., Muratore, J.F., 1982. Nitrogen and lignin control of hardwood leaf litter decomposition dynamics. Ecology 63, 621-626.

Metcalfe, D.B., Meir, P., Aragão, L.E.O.C., Malhi, Y., da Costa, A.C.L., Braga, A., Gonçalves, P.H.L., de Athaydes, J., de Almeida, S.S., Williams, M., 2007. Factors controlling spatio-temporal variation in carbon dioxide efflux from surface litter, roots, and soil organic matter at four rain forest sites in the eastern Amazon. J. Geophys. Res. Biogeosci. 112, 1-9. https://doi.org/10.1029/2007JG000443.

O'Connell, A.M., 1990. Microbial decomposition (respiration) of litter in eucalypt forests of South-Western Australia: an empirical model based on laboratory incubations. Soil Biol. Biochem. 22, 153-160. https://doi.org/10.1016/0038-0717(90)90080-J.

Olsen, H.R., Van Miegroet, H., 2010. Factors affecting carbon dioxide release from forest and rangeland soils in Northern Utah. Soil Sci. Soc. Am. J. 74, 282. https://doi.org/ $10.2136 /$ sssaj2009.0095.

Peñuelas, J., Boada, M., 2003. A global change-induced biome shift in the Montseny mountains (NE Spain). Glob. Change Biol. 9, 131-140. https://doi.org/10.1046/j. 1365-2486.2003.00566.x.

Phillips, C.L., Bond-Lamberty, B., Desai, A.R., Lavoie, M., Risk, D., Tang, J., Todd-Brown, K., Vargas, R., 2016. The value of soil respiration measurements for interpreting and modeling terrestrial carbon cycling. Plant Soil 1-25. https://doi.org/10.1007/ s11104-016-3084-x.

Pohlert, T., 2015. The pairwise multiple comparison of mean ranks package (PMCMR).

Poyatos, R., Llorens, P., Gallart, F., 2005. Transpiration of montane Pinus sylvestris L. and Quercus pubescens Willd. forest stands measured with sap flow sensors in NE Spain. Hydrol. Earth Syst. Sci. Discuss. 2, 1011-1046. https://doi.org/10.5194/hessd-21011-2005.

Pumpanen, J., Kolari, P., Ilvesniemi, H., Minkkinen, K., Vesala, T., Niinistö, S., Lohila, A. Larmola, T., Morero, M., Pihlatie, M., Janssens, I., Yuste, J.C., Grünzweig, J.M., Reth, S., Subke, J.-A., Savage, K., Kutsch, W., Østreng, G., Ziegler, W., Anthoni, P., Lindroth, A., Hari, P., 2004. Comparison of different chamber techniques for measuring soil $\mathrm{CO}_{2}$ efflux. Agric. For. Meteorol. 123, 159-176. https://doi.org/10.1016/ j.agrformet. 2003.12.001.

R Core Team, 2017. R: A Language and Environment for Statistical Computing.

Raich, J.W., Tufekcioglu, A., 2000. Vegetation and soil respiration: correlations and controls. Biogeochemistry 48, 71-90. https://doi.org/10.1023/A:1006112000616.

Reichstein, M., Rey, A., Freibauer, A., Tenhunen, J., Valentini, R., Banza, J., Casals, P., Cheng, Y., Grünzweig, J.M., Irvine, J., Joffre, R., Law, B.E., Loustau, D., Miglietta, F., Oechel, W., Ourcival, J., Pereira, J.S., Peressotti, A., Ponti, F., Qi, Y., Rambal, S., Rayment, M., Romanya, J., Rossi, F., Tedeschi, V., Tirone, G., Xu, M., Yakir, D., 2003. Modeling temporal and large-scale spatial variability of soil respiration from soil water availability, temperature and vegetation productivity indices. Global Biogeochem. Cycles 17, 1-15. https://doi.org/10.1029/2003GB002035.

Rey, A., Emiliano, P., Vanessa, T., de parri, Ilaria, Jarvis, P.G., Valentini, R., 2002. Annua variation in soil respiration and its components in a coppice oak forests in Central Italy. Glob. Change Biol. 8, 851-866. https://doi.org/10.1017/CBO9781107415324. 004.

Ruiz-Peinado, R., Del Rio, M., Montero, G., 2011. New models for estimating the carbon sink capacity of Spanish softwood species. For. Syst. 20, 176-188. https://doi.org/10. 5424/fs/2011201-11643.

Sabaté, S., Gracia, C.A., Sánchez, A., 2002. Likely effects of climate change on growth of Quercus ilex, Pinus halepensis, Pinus pinaster, Pinus sylvestris and Fagus sylvatica forests in the Mediterranean region. For. Ecol. Manage. 162, 23-37. https://doi.org/10. 1016/S0378-1127(02)00048-8.

Saiz, G., Black, K., Reidy, B., Lopez, S., Farrell, E.P., 2007. Assessment of soil $\mathrm{CO}_{2}$ efflux and its components using a process-based model in a young temperate forest site. Geoderma 139, 79-89. https://doi.org/10.1016/j.geoderma.2006.12.005.

Salomón, R., Rodríguez-Calcerrada, J., Zafra, E., Morales-Molino, C., Rodríguez-García, A., González-Doncel, I., Oleksyn, J., Zytkowiak, R., López, R., Miranda, J.C., Gil, L., Valbuena-Carabaña, M., 2016a. Unearthing the roots of degradation of Quercus pyrenaica coppices: a root-to-shoot imbalance caused by historical management? For. Ecol. Manage. 363, 200-211. https://doi.org/10.1016/j. foreco.2015.12.040.

Salomón, R., Valbuena-Carabana, M., Gil, L., McGuire, M.A., Teskey, R.O., Aubrey, D.P., Gonzalez-Doncel, I., Rodríguez-Calcerrada, J., 2016b. Temporal and spatial patterns of internal and external stem $\mathrm{CO}_{2}$ fluxes in a sub-Mediterranean oak. Tree Physiol. 36, 1409-1421. https://doi.org/10.1093/treephys/tpw029.

Salomón, R., Valbuena-Carabaña, M., Rodríguez-Calcerrada, J., Aubrey, D., McGuire, M.A., Teskey, R., Gil, L., González-Doncel, I., 2015. Xylem and soil $\mathrm{CO}_{2}$ fluxes in a Quercus pyrenaica Willd. coppice: root respiration increases with clonal size. Ann. For. Sci. 72, 1065-1078. https://doi.org/10.1007/s13595-015-0504-7.

Sánchez-Salguero, R., Camarero, J.J., Hevia, A., Madrigal-González, J., Linares, J.C., Ballesteros-Canovas, J.A., Sánchez-Miranda, A., Alfaro-Sánchez, R., SangüesaBarreda, G., Galván, J.D., Gutiérrez, E., Génova, M., Rigling, A., 2015. What drives 
growth of Scots pine in continental Mediterranean climates: drought, low temperatures or both? Agric. For. Meteorol. 206, 151-162. https://doi.org/10.1016/j. agrformet.2015.03.004

Sánchez Palomares, O., Roig, S., Del Río, M., Rubio, A., Gandullo, J.M., 2008. Las estaciones ecológicas actuales y potenciales de los rebollares españoles. Instituto Nacional de Investigación y Tecnología Agraria y Alimentaria. Ministerio de Ciencia e Innovación. Monografías INIA: Serie Forestal, No 17.

Sarkar, D., 2008. Lattice: Multivariate Data Visualization with R. Springer, New York.

Soil Survey Staff, 2014. Keys to Soil Taxonomy, 12th ed. USDA-Natural Resources Conservation Service, Washington, DC.

Stagge, J.H., Kingston, D.G., Tallaksen, L.M., Hannah, D.M., 2017. Observed drought indices show increasing divergence across Europe. Sci. Rep. 7, 14045. https://doi. org/10.1038/s41598-017-14283-2.

Tedeschi, V., Rey, A., Manca, G., Valentini, R., Jarvis, P.J., Borghetti, M., 2006. Soil re spiration in a Mediterranean oak forest at different developmental stages after coppicing. Glob. Change Biol. 12, 110-121. https://doi.org/10.1111/j.1365-2486.2005 01081.x.

Thornthwaite, C.W., Mather, J.R., 1955. The Water Balance, Publications in Climatology. Laboratory of Climatology. Drexel Institute of Technology, Centerton, N.J.
Tuomi, M., Vanhala, P., Karhu, K., Fritze, H., Liski, J., 2008. Heterotrophic soil respiration-Comparison of different models describing its temperature dependence. Ecol. Model. 211, 182-190. https://doi.org/10.1016/j.ecolmodel.2007.09.003.

Ubierna, N., Kumar, A.S., Cernusak, L.A., Pangle, R.E., Gag, P.J., Marshall, J.D., 2009. Storage and transpiration have negligible effects on $813 \mathrm{C}$ of stem $\mathrm{CO}_{2}$ efflux in large conifer trees. Tree Physiol. 29, 1563-1574. https://doi.org/10.1093/treephys ! tpp089.

Vayreda, J., Martínez-Vilalta, J., Gracia, M., Retana, J., 2012. Recent climate changes interact with stand structure and management to determine changes in tree carbon stocks in Spanish forests. Glob. Change Biol. 18, 1028-1041. https://doi.org/10. $1111 /$ j.1365-2486.2011.02606.x.

Wickham, H., 2009. goplot2: Elegant Graphics for Data Analysis. Springer-Verlag, New York.

Ximénez de Embún, J., 1977. El monte bajo. Ministerio de Agricultura, Madrid.

Zhu, W.Z., Xiang, J.S., Wang, S.G., Li, M.H., 2012. Resprouting ability and mobile carbohydrate reserves in an oak shrubland decline with increasing elevation on the eastern edge of the Qinghai-Tibet Plateau. For. Ecol. Manage. 278, 118-126. https:// doi.org/10.1016/j.foreco.2012.04.032 